\title{
Native Gold in the Chudnoe Au-Pd-REE Deposit (Subpolar Urals, Russia): Composition, Minerals in Intergrowth and Genesis
}

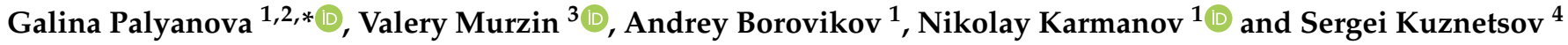 \\ 1 Sobolev Institute of Geology and Mineralogy, Siberian Branch of Russian Academy of Sciences, Akademika \\ Koptyuga Pr., 3, 630090 Novosibirsk, Russia; borovikov.57@mail.ru (A.B.); krm@igm.nsc.ru (N.K.) \\ 2 Department of Geology and Geophysics, Novosibirsk State University, Pirogova Str., 2, \\ 630090 Novosibirsk, Russia \\ 3 Zavaritsky Institute of Geology and Geochemistry, Ural Branch of Russian Academy of Sciences, Akademika \\ Vonsovskogo Str., 15, 620016 Ekaterinburg, Russia; murzin@igg.uran.ru \\ 4 Komi Science Center, Institute of Geology, Ural Branch, Russian Academy of Sciences, Pervomaiskaya Str., 54, \\ 167982 Syktyvkar, Russia; kuznetsov@geo.komisc.ru \\ * Correspondence: palyan@igm.nsc.ru
}

check for updates

Citation: Palyanova, G.; Murzin, V.; Borovikov, A.; Karmanov, N.; Kuznetsov, S. Native Gold in the Chudnoe Au-Pd-REE Deposit (Subpolar Urals, Russia): Composition, Minerals in Intergrowth and Genesis. Minerals 2021, 11, 451. https://doi.org/10.3390/min11050451

Academic Editor: Theodore

J. Bornhorst

Received: 20 February 2021

Accepted: 22 April 2021

Published: 25 April 2021

Publisher's Note: MDPI stays neutral with regard to jurisdictional claims in published maps and institutional affiliations.

Copyright: (c) 2021 by the authors. Licensee MDPI, Basel, Switzerland. This article is an open access article distributed under the terms and conditions of the Creative Commons Attribution (CC BY) license (https:/ / creativecommons.org/licenses/by/ $4.0 /)$.

\begin{abstract}
Composition of native gold and minerals in intergrowth of the Chudnoe Au-Pd-REE deposit (Subpolar Urals, Russia) was studied using optical microscopy, scanning electron microscopy, and electron microprobe analysis. Five varieties of native gold have been identified, based on the set of impurity elements and their quantities, and on intergrown minerals. Native gold in rhyolites from the Ludnaya ore zone is homogeneous and contains only Ag (fineness 720\%, type I). It is in intergrowth with fuchsite or allanite and mertieite-II. In rhyolites from the Slavnaya ore zone, native gold is heterogeneous, has a higher fineness, different sets and contents of elements: $\mathrm{Ag}, \mathrm{Cu}, 840$ 860\% (type II); Ag, Cu, Pd, 830-890\%o (III); Ag, Pd, Cu, Hg, 840-870\%o (IV). It occurs in intergrowth with fuchsite, albite, and mertieite-II (type II), or albite, quartz, and atheneite (III), or quartz, albite, Kfeldspar, and mertieite-II (IV). High-fineness gold (930-1000\%, type V) with low contents of Ag, Cu, and Pd or their absence occurs in the form as microveins, fringes and microinclusions in native gold II-IV. Tetra-auricupride $(\mathrm{AuCu})$ is presented as isometric inclusions in native gold II and platelets in the decay structures in native gold III and IV. The preliminary data of a fluid inclusions study showed that gold mineralization at the Chudnoe deposit could have been formed by chloride fluids of low and medium salinity at temperatures from 105 to $230{ }^{\circ} \mathrm{C}$ and pressures from 5 to $115 \mathrm{MPa}$. The formation of native gold I is probably related to fuchsitization and allanitization of rhyolites. The formation of native gold II-V is also associated with the same processes, but it is more complicated and occurred later with a significant role of $\mathrm{Na}-, \mathrm{Si}-$, and $\mathrm{K}$-metasomatism. The presence of $\mathrm{Pd}$ and $\mathrm{Cu}$ in the ores and $\mathrm{Cr}$ in fuchsite indicates the important role of mafic-ultramafic magmatism.
\end{abstract}

Keywords: Chudnoe deposit (Russia); Au-Pd-REE mineralization; chemistry of native gold; Au-Cu intermetallides; $\mathrm{P}, \mathrm{T}, \mathrm{X}$ parameters of ore-forming fluids

\section{Introduction}

The Chudnoe deposit (Subpolar Urals, Russia) [1-3] and some other Ural depositsBaronskoe [4], Volkovskoe, Nesterovskoe [1,3,5-7], and Ozernoe [8,9] are unique in the set of impurity elements in native gold $(\mathrm{Ag}, \mathrm{Cu}, \mathrm{Pd}, \mathrm{Hg})$, variability of their concentrations, and minerals in intergrowth with it. The Chudnoe deposit is a special type of Au-Pd-REE mineralization [1,3], which differs from the known hydrothermal or metamorphic gold deposits. Native gold at this deposit is associated with chromium muscovite (fuchsite), REE minerals, palladium arsenoantimonides in the absence of iron sulfides and carbonates. It was discovered by Ozerov in 1994 [10] on the eastern slope of the Maldynyrd ridge during prospecting works on primary deposits, which are probable sources of earlier discovered 
placers with gold and palladium minerals in the Kozhim district. Since that time, numerous papers have been published on the mineralogy of the Chudnoe deposit in the form of a number of publications in the proceedings of Russian conferences, one monograph [3], three Ph.D. theses [5,11,12], and about ten articles [1-3,7,13-16].

In the earlier works on the mineralogy of gold from the Chudnoe deposit the authors distinguish from one to three varieties of native gold $[1-3,16]$. Native gold contains major (>10 wt. $\%)$, minor (1-10 wt. $\%)$, and trace ( $<1 \mathrm{wt} . \%)$ elements. The first data on the composition of native gold were reported by Tarbaev and coauthors [1], revealing that gold particles are concentrated near fuchsite veinlets. The first variety is the products of decomposition of $\mathrm{Ag}-\mathrm{Cu}-\mathrm{Hg}-\mathrm{Pd}$ solid solution. The matrix is depleted in $\mathrm{Pd}$ (0.3-0.8 wt.\%) relative to the Au-Cu phase of the platelets (0.7-1.1 wt.\% Pd) and has a fineness of $840-870 \%\left(\mathrm{~N}_{\mathrm{Au}}=\mathrm{Au} \times 1000 /(\mathrm{Au}+\mathrm{Ag}+\mathrm{Cu}+\mathrm{Hg}+\mathrm{Pd})\right)$. The composition of platelets (1-2 $\mu \mathrm{m}$ thick and to $10 \mu \mathrm{m}$ long) was determined approximately: maximum content of $\mathrm{Cu}$ is $10.5 \mathrm{wt} . \%$, the amount of $\mathrm{Hg}$ is close to that in the matrix $0.1-1 \mathrm{wt} . \%$, and Ag ranges from 2.5 to $11.6 \mathrm{wt}$. $\%$. The second variety of native gold is represented by a higher fineness (to $1.9 \mathrm{wt} . \% \mathrm{Pd}$ ) porous gold in the form of isometric 3-15 $\mu \mathrm{m}$ inclusions in native gold of the first type or thin rims around it.

Galankina et al. [2] found one variety of native gold with high concentrations of $\mathrm{Ag}$ (to 20-25, occasionally to $50.5 \mathrm{wt} . \%$ ) and low concentrations of $\mathrm{Cu}$ and $\mathrm{Pd}$ (no more than $0.2 \mathrm{wt}$ \%) (fineness $510-800 \%$ ) in the absence of $\mathrm{Hg}$. Gold particles to $3 \mathrm{~mm}$ in size were concentrated in fuchsite-quartz-allanite veinlets and often in intergrowth with mertieite or contained its inclusions. Shumilov and Ostashchenko [3] revealed three varieties of that native gold from the Chudnoe deposit, which are associated with either fuchsite or allanite localized in the axial part of mica veinlets. Native gold with a wide range of impurities, to $2.3 \mathrm{wt} . \% \mathrm{Pd}$, to $3.6 \mathrm{wt} . \% \mathrm{Cu}$, and to $1.4 \mathrm{wt} . \% \mathrm{Hg}(840-870 \%$ ), was attributed to the first type. It has an intricate inner structure: some of gold particles (840-870\%o) are rimmed with high-fineness gold (920-990\%) only with an impurity of $\mathrm{Cu}$, whereas other gold particles contained the decomposition products of solid solutions. The platelets are from 0.1 to $1-3 \mu \mathrm{m}$ thick, the amount of $\mathrm{Cu}$ in the platelets is higher (increase to 12.5 instead of 3-4 wt.\%), and that of Ag is lower than in the matrix (decreases from 11-12 to 3-4 wt.\%). Native gold of the second type is characterized by a low fineness $(720-790 \%$, as low as $530 \%$ ) and absence of $\mathrm{Cu}, \mathrm{Hg}$, and $\mathrm{Pd}$. This type of native gold occurs in the Ludnaya zone. To the third type, these authors [3] attribute porous and microcrystalline native gold that overgrows on larger gold particles of the first and second types. It is characterized by high fineness (to $990 \%$ ) and, respectively, lower contents of $\mathrm{Ag}$ and $\mathrm{Cu}$ at relatively high concentrations of $\mathrm{Pd}$ and absence of $\mathrm{Hg}$.

Borisov [5] found that native gold from the Chudnoe deposit contained inclusions of the $\mathrm{Au}-\mathrm{Cu}$ phases: $\mathrm{Au}_{3} \mathrm{Cu}, \mathrm{Au}_{3} \mathrm{Cu}_{2}$, and $\mathrm{Au}_{2} \mathrm{Cu}$ with minor Pd. Kuznetsov et al. [8] also reported that native gold of heterogeneous composition (8.2-11.6 wt.\% Ag, $1.3-3.0 \mathrm{wt} . \% \mathrm{Cu}$, about $1.3 \mathrm{wt} . \% \mathrm{Hg}$ and to $1.7 \mathrm{wt} . \% \mathrm{Pd}$, fineness 850-906\%) contains inclusions of $\mathrm{Au}-$ $\mathrm{Cu}$ phases-tetra-auricupride $\mathrm{AuCu}$ and auricupride $\mathrm{AuCu}_{3}$ and $\mathrm{Pd}$ minerals-mertieite $\mathrm{Pd}_{5} \mathrm{Sb}_{2}$, isomertieite $\mathrm{Pd}_{5} \mathrm{AsSb}$, atheneite $(\mathrm{Pd}, \mathrm{Hg})_{3} \mathrm{As}$, stillwaterite $\mathrm{Pd}_{8} \mathrm{As}_{3}$, and stibiopalladinite $\mathrm{Pd}_{5} \mathrm{Sb}_{3}$. It is worth noting that the stoichiometric formulas of some minerals reported by these authors differ from those of minerals with similar names from the IMA database [17]: mertieite-I $\mathrm{Pd}_{5+x}(\mathrm{Sb}, \mathrm{As})_{2-x}(x=0.1-0.2)$, mertieite-II $\mathrm{Pd}_{8} \mathrm{Sb}_{2.5} \mathrm{As}_{0.5}$, omertieite $\mathrm{Pd}_{11} \mathrm{Sb}_{2} \mathrm{As}_{2}$, stibiopalladinite $\mathrm{Pd}_{5} \mathrm{Sb}_{2}$, atheneite $\mathrm{Pd}_{2}\left(\mathrm{As}_{0.75} \mathrm{Hg}_{0.25}\right)$. Onishchenko et al. [16] determined two varieties of native gold in the Slavnaya ore zone at the Chudnoe deposit. The authors show a predominance of native gold containing $84-88 \mathrm{wt} . \% \mathrm{Au}, 7-12 \mathrm{wt} . \% \mathrm{Ag}, 1.3-5.5 \mathrm{wt} . \% \mathrm{Cu}$, $1-2 \mathrm{wt} . \% \mathrm{Pd}$ and about $1 \mathrm{wt} . \% \mathrm{Hg}$. This native gold was found to be intergrown with small inclusions of high-fineness gold: $94-98 \mathrm{wt} . \% \mathrm{Au}, 1.5-2 \mathrm{wt} . \% \mathrm{Pd}$, to $0.9 \mathrm{wt} . \% \mathrm{Cu}$ and to 0.7 wt. $\%$ Ag. 
Despite the numerous results, the reasons of compositional changes in native gold and the presence of a wide set of impurity elements are not clear yet. Although native gold is known to be concentrated in the fuchsite veinlets in rhyolites, there is little information on matrix minerals in close growth with it and physicochemical conditions of the formation of Au-Pd-REE mineralization. The aim of our study is to reveal the specific features of the chemical composition of native gold and to determine the minerals in the intergrowth with it in the Slavnaya and Ludnaya ore zones of the Chudnoe deposit. The first results of the fluid inclusions study at the Chudnoe deposit were obtained by Surenkov [12]. This study provides limited new microthermometric analyses of fluid inclusions which are used to estimate the compositional features and PTX parameters for two ore zones. These data will help us to determine the possible sources of trace elements in native gold and to receive new information on the genesis of unique Chudnoe Au-Pd-REE deposit.

\section{Geological Settings and Localizations}

The Chudnoe deposit occurs on the western slope of the Subpolar Urals (Russia) in the interformational contact zone of uralids (terrigeneous and sedimentary rocks $\mathrm{O}_{1-2}$ ) and preuralids (volcanogenic rocks of effusive and subvolcanic facies of acidic and basic composition $\mathrm{R}_{3}-\mathrm{V}$ ) in the axial part of the Maldinskaya anticline. In the contact zone of the Precambrian and Ordovician rocks there are lenses of chloritoid-pyrophylite slates which are considered to be the relicts of metamorphosed weathering crusts of the Precambrian age [10].

Numerous dislocations with a break in continuity of mainly NE strike are developed in the area of the deposit. The largest of them is the Maldinskiy fault, a zone in which the Chudnoe deposit is localized [1,7]. Metasomatites and associated zones of pyritization, hydrothermal quartz veins, many of which are crystal-bearing, are widespread in the area. Occurrences of rare-earth, polymetallic, molybdenum, silver, and uranium-copper mineralization are present as well. Lying 1.5-2 km to the southeast of the Chudnoe deposit is the Nesterovskoe occurrence localized in the terrigenous formations of uralids (aleuroschists, sandstones and gritstone $\mathrm{O}_{1}$ ) with gold-platinoid-fuchsite mineralization. Gold-palladium mineralization formed much later than the host rocks and it is of Paleozoic age (250-260 Ma), according to the ${ }^{39} \mathrm{Ar}-{ }^{40} \mathrm{Ar}$ datings on fuchsite [13].

The northwestern part of the Chudnoe deposit is composed of rocks of basic composition rich in $\mathrm{Na}$ (Figure 1). These rocks consist of metabasalts transformed into dark-gray schists and, to a lesser degree, of metadolerites and gabbrodolerites of more massive appearance [7]. Alterations of rocks develop as chloritization, albitization, and epidotization. The accessory minerals of metabasic rocks are magnetite, ilmenite, titanite, and sulfides (pyrite, chalcopyrite). The content of gold in basaltoids is insignificant.

The southeastern part of the deposit area is made up of mainly dark porphyric rhyolites with flow bandings. Along the dislocations with a break in continuity, rhyolites are often lightened. In addition, dark rhyolites contain lightened zones extending to $1 \mathrm{~m}$, oriented according to fluidality. The dark color of rhyolites is due to the scattered fine (to $0.01 \mathrm{~mm}$ ) impregnations of hematite, which is absent in light rocks [14]. The groundmass of rhyolites is composed of varying amounts of quartz, albite, K-feldspar, and sericite. The accessory minerals of rhyolites are ilmenite, titanite, allanite, apatite, zircon, monazite, and xenotime. As for dark rhyolites, lightened zones contain similar quantities of major components and low concentrations of $\mathrm{Fe}_{2} \mathrm{O}_{3}$ (Table 1). 


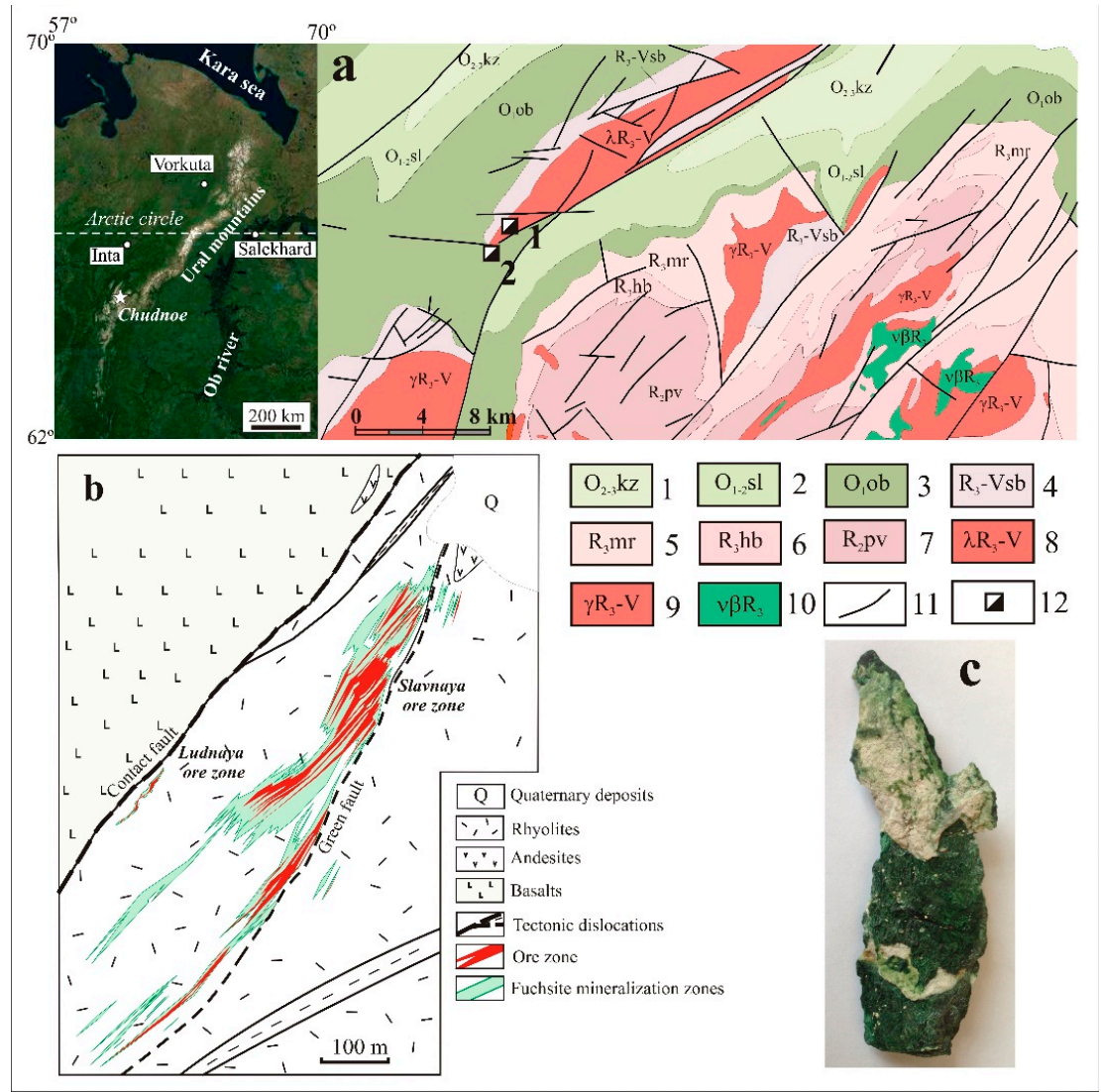

Figure 1. 200-km (inset), 8-km (a), and 100-m (b) scale maps of the Chudnoe deposit according to [7] and photograph of ore sample (size $5 \mathrm{~cm} \times 13 \mathrm{~cm}$ ) from this deposit $(\mathrm{c})$. 1-Kozhim Formation: limestones, calcareous shales and sandstones; 2-Saled Formation: chlorite-sericite-quartz shale, sandstone; 3-Obizskaya suite: quartzite sandstones, conglomerates, gravelstones; 4-Sablegorskaya suite: felsic and basic effusive rocks, tuffs, phyllitic schists; 5-Moroinskaya Formation ( $\left.\mathrm{R}_{3} \mathrm{mr}\right)$ : phyllitic schists, marbles, quartzites; 6 -Khobein suite: quartzites, conglomerates, chlorite-sericitequartz schists; 7-Puivinskaya suite: mica-quartz schists, calcareous schists, interlayers of quartzites, marbles; 8-subvolcanic rhyolites; 9-granites; 10-gabbro, gabbro-dolerites; 11—tectonic faults; 12-Chudnoe (1) and Nesterovskoe (2) deposits.

Table 1. Chemical composition of light (L) and dark (D) rhyolites from the Chudnoe deposit [14].

\begin{tabular}{|c|c|c|c|c|c|c|c|c|c|c|c|c|c|}
\hline No. & $\mathrm{SiO}_{2}$ & $\mathrm{TiO}_{2}$ & $\mathrm{Al}_{2} \mathrm{O}_{3}$ & $\mathrm{Fe}_{2} \mathrm{O}_{3}$ & $\mathrm{FeO}$ & $\mathrm{MnO}$ & $\mathrm{MgO}$ & $\mathrm{CaO}$ & $\mathrm{Na}_{2} \mathrm{O}$ & $\mathrm{K}_{2} \mathrm{O}$ & $\mathrm{P}_{2} \mathrm{O}_{5}$ & LOI & $\Sigma$ \\
\hline $41 \mathrm{~L}$ & 77.32 & 0.17 & 11.63 & 0.62 & 0.50 & 0.02 & 0.06 & 0.19 & 1.99 & 6.40 & 0.02 & 0.21 & 99.13 \\
\hline $42 \mathrm{D}$ & 75.08 & 0.17 & 11.75 & 2.40 & 0.72 & 0.02 & 0.09 & 0.18 & 1.72 & 6.60 & 0.02 & 0.41 & 99.16 \\
\hline $43 \mathrm{~L}$ & 76.42 & 0.17 & 12.14 & 1.00 & 0.65 & 0.02 & 0.10 & 0.16 & 1.85 & 6.60 & 0.02 & 0.27 & 99.40 \\
\hline $44 \mathrm{D}$ & 73.56 & 0.19 & 12.64 & 2.55 & 0.65 & 0.04 & 0.16 & 0.37 & 1.45 & 6.60 & 0.05 & 0.74 & 99.00 \\
\hline $62 \mathrm{~L}$ & 75.44 & 0.19 & 13.66 & 0.50 & 1.01 & 0.02 & 0.04 & 0.21 & 4.90 & 3.60 & 0.03 & 0.14 & 99.74 \\
\hline $63 \mathrm{D}$ & 73.06 & 0.19 & 14.29 & 1.49 & 0.79 & 0.02 & 0.06 & 0.23 & 4.80 & 3.80 & 0.04 & 0.38 & 99.15 \\
\hline $64 \mathrm{~L}$ & 74.94 & 0.19 & 13.91 & 0.30 & 0.58 & 0.02 & 0.01 & 0.22 & 5.70 & 3.10 & 0.02 & 0.05 & 99.04 \\
\hline $65 \mathrm{D}$ & 75.34 & 0.19 & 13.15 & 1.86 & 0.65 & 0.02 & 0.05 & 0.23 & 5.00 & 3.20 & 0.02 & 0.21 & 99.92 \\
\hline $21 \mathrm{~L}$ & 77.76 & 0.17 & 12.17 & 0.13 & 0.60 & 0.01 & 0.04 & 0.15 & 2.78 & 5.70 & 0.02 & 0.18 & 99.71 \\
\hline $22 \mathrm{D}$ & 75.36 & 0.18 & 12.68 & 1.78 & 0.43 & 0.01 & 0.06 & 0.14 & 2.90 & 5.30 & 0.02 & 0.27 & 99.13 \\
\hline $71 \mathrm{~L}$ & 73.42 & 0.19 & 14.20 & 0.21 & 0.86 & 0.01 & 0.06 & 0.17 & 4.50 & 5.70 & 0.03 & 0.15 & 99.53 \\
\hline $72 \mathrm{D}$ & 72.00 & 0.19 & 14.54 & 2.41 & 0.29 & 0.02 & 0.05 & 0.16 & 5.60 & 4.70 & 0.02 & 0.17 & 100.15 \\
\hline 4-2 L & 78.92 & 0.10 & 10.80 & 0.37 & 1.22 & 0.01 & 0.10 & 0.18 & 3.67 & 3.40 & 0.02 & 0.6 & 99.39 \\
\hline $4-1 \mathrm{D}$ & 75.67 & 0.12 & 12.11 & 1.59 & 1.08 & 0.01 & 0.12 & 0.20 & 4.41 & 3.65 & 0.02 & 0.4 & 99.38 \\
\hline
\end{tabular}

Notes: The $\mathrm{CO}_{2}$ content in the samples does not exceed $0.22 \mathrm{wt} . \%$, the $\mathrm{F}$ content $<0.02 \mathrm{wt} . \%$. LOI-loss on ignition. 
Onishchenko and Kuznetsov [7] report that in gold-bearing rhyolites, the content of $\mathrm{Cr}$ reaches 0.03-0.05 wt.\%, and the concentrations of $\mathrm{Au}, \mathrm{Ag}$ and As are no more than few tens of ppm: $25 \mathrm{Au}, 3.4 \mathrm{Ag}$ (which corresponds to Au/Ag $\approx 7$ ), and 6-21 As. The contents of some elements amount to hundreds of ppm: 480-970 Ba, 80-100 La, 160-230 Ce, 60-110 Y, 30-40 Nb, 180-260 Zr. The total contents of REE in rhyolites with fuchsite from the Chudnoe deposit average 544 ppm [5]. The concentrations of $\mathrm{Hg}$ to $18 \mathrm{ppm}$ are typical of fuchsite ores, barren rhyolites contain up to $18 \mathrm{ppb} \mathrm{Hg}$ [18]. In gold-bearing rhyolites the content of $S$ is no more than $0.01 \mathrm{wt}$.\%. Higher sulfur contents (to $0.5 \mathrm{wt}$.\%) were found in some poorly productive zones among andesites [7].

Au-Pd-REE mineralization occurs in several schist and brecciate zones 100 to $460 \mathrm{~m}$ in length and up to $60 \mathrm{~m}$ in thickness in rhyolites (Figure 1). The ore zones have a steep $\left(50-70^{\circ}\right)$ northwestern dip and northeastern strike. Au-Pd-REE mineralization in the schist and brecciated zones occurs among fuchsite, quartz, and quartz-albite veinlets ranging in thickness from few $\mathrm{mm}$ to $1-1.5 \mathrm{~cm}$. The Chudnoe deposit includes the Slavnaya and Lyudnaya ore zones (Figure 1). The main zone is the Slavnaya located in the central part of the deposit. This zone contains the richest ores with highest Au concentrations $\sim 22 \mathrm{ppm}$ [7]. A rather small Ludnaya ore zone is localized in schistose rhyolites at the contact with mafic rocks (andesites and basalts). It occurs to the southwest of the Slavnaya ore zone at a distance of 200-250 $\mathrm{m}$ and rises for $50 \mathrm{~m}$ above the relief [3]. The Ludnaya ore zone has a lentiform-discontinuous structure and contains rich ores with visible native gold. The content of noble metals is nonuniform - from few to hundreds ppm.

\section{Materials and Methods}

Samples of Au-bearing rhyolites collected from exploration trenches were used. Numerous polished and thin sections were made of them. For our study we selected typical samples of rhyolite from the ore zones Ludnaya (No.1a-1154-6; No.1b-1154-6b) (Figure 2a) and Slavnaya (No.2-1122-5, No.3-1122-12, No.4a-1122-1, No.4b-1122-1b; No.5-1122-13) (Figures 6a-8a), in which native gold was found visually or under a microscope.

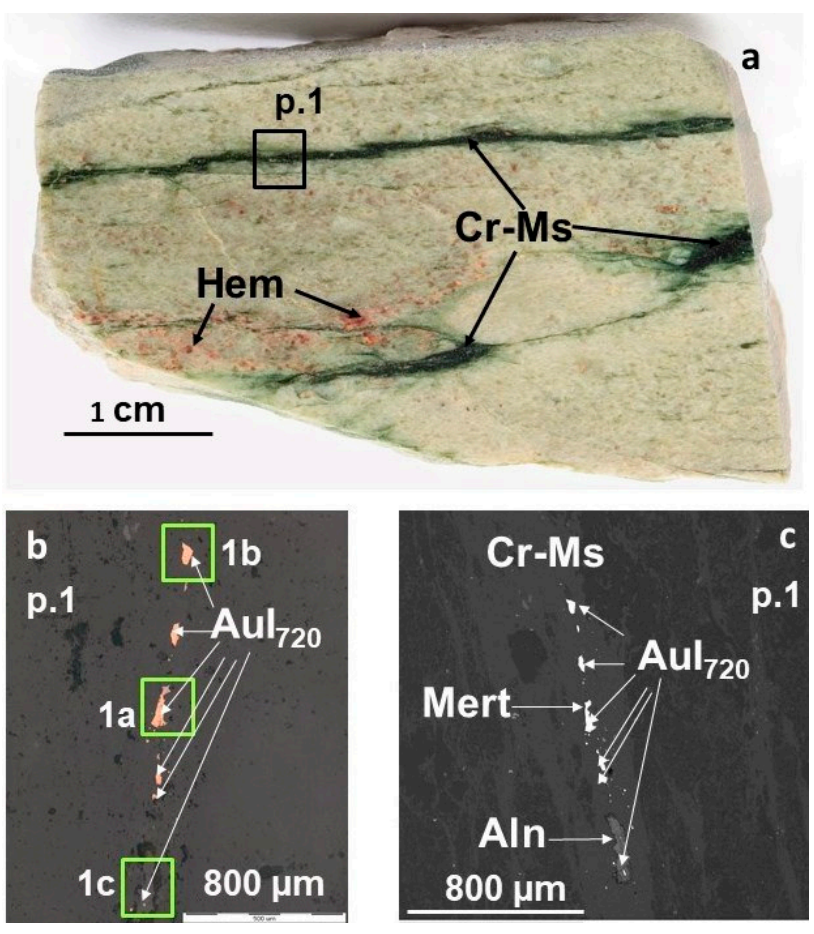

Figure 2. Macrophotograph of a polished section of rhyolite from the Ludnaya zone (a) and reflected light microscopy image (b) and BSE (c) micrograph of its fragment (p.1) with a fuchsite (Cr-Ms) veinlet containing native gold of type I (AuI), allanite (Aln), and mertieite (Mert). 
A macro- and microscopic study of the ore samples was conducted. Mineralogical research was carried out using an optical microscope Olympus BX51 (in the Sobolev Institute of Geology and Mineralogy of the Siberian Branch of the Russian Academy of Sciences (IGM SB RAS) (Novosibirsk, Russia). Chemical analyses of minerals were conducted at the Analytical Center for Multi-elemental and Isotope Research in the IGM SB RAS (Novosibirsk, Russia) by electron probe microanalysis (EPMA) using a MIRA 3 LMU scanning electron microscope (Tescan Orsay Holding, Brno, Czech Republic) equipped with an X-ray energy dispersive spectrometer (EDS) AZtec Energy XMax-50 (Oxford Instruments Nanoanalysis, Oxford, UK) (analysts Dr. N. Karmanov, M. Khlestov).

The composition of native gold and accessory minerals was studied at the following parameters: accelerating voltage was $20 \mathrm{kV}$, live spectrum acquisition time was $60 \mathrm{sec}$ (total area of spectra $\sim 10^{6}$ counts). The following $\mathrm{X}$-rays were selected: $\mathrm{K}$ series for $\mathrm{Fe}, \mathrm{Cu}, \mathrm{As}$ and $L$ series for $\mathrm{Pd}, \mathrm{Ag}, \mathrm{Sb}, \mathrm{Au}, \mathrm{Hg}$. We used pure metals $(\mathrm{Fe}, \mathrm{Cu}, \mathrm{Pd}, \mathrm{Ag}, \mathrm{Au})$ and InAs for As and $\mathrm{HgTe}$ for $\mathrm{Hg}$ as the standards. The detection limits (in wt.\%) were: $0.1 \mathrm{Fe}, 0.15 \mathrm{Cu}$, $0.25 \mathrm{Pd}, \mathrm{Ag}, \mathrm{Sb}, 0.3 \mathrm{As}, 0.6 \mathrm{Au}$, and $0.8 \mathrm{Hg}$. Error in determining the main components with the contents higher than $10 \mathrm{wt} . \%$ did not exceed 1 relative (rel.) \%, and when the content of components ranged 2-10 wt.\%, the error was no higher than 6-8 rel. \%. Close to the limit of detection, the error was 15-20 rel. \%. In some cases the spectrum acquisition time increased to $120 \mathrm{~s}$, the lower limits of determined contents and the random error of the analysis decreased about 1.4 times. To reduce the effect of microrelief of samples on the quality of analysis, data on the primary homogeneous gold were obtained in the scanning mode of individual sections from $10 \times 10$ to $50 \times 50 \mu \mathrm{m}^{2}$ in size. In the same mode, we obtained the average composition of native gold in the presence of decay structures. The compositions of small gold particles $(<10 \mu \mathrm{m})$ and platelets of decay structure were determined with a $10 \mathrm{~nm}$ point probe, but the size of the generation region of $X$-ray emission in gold with the electron beam energy $20 \mathrm{kV}$ was $1 \mu \mathrm{m}$. Therefore, the data of analysis cannot be considered quantitative if the minimum size of the studied object is less than $2 \mu \mathrm{m}$.

It is worth noting that in the obtained back scattered-electron (BSE) micrographs, albite and quartz as well as K-feldspar and muscovite (fuchsite) are hardly distinguishable when they are intergrown with each other. For better visualization of the matrix minerals, we used multi-layered colorful EDS maps.

Fluid inclusion microthermometry was used to analyze the composition of fluids and to estimate the pressure-temperature conditions during ore forming processes (fluid inclusion study was carried out in the Laboratory of Prediction-Metallogenic studies, IGM SB RAS, Novosibirsk, Russia). Phase transition temperatures in fluid inclusions (samples No.1b-1154-6b; No.4b-1122-1b) were determined using cryo- and thermometry procedures (Linkam THMSG-600 heating-freezing chamber with the measurement range of -196 to $+600{ }^{\circ} \mathrm{C}$ ). According to the data of cryometry, the fluids are attributed to the water-salt system $[19,20]$. To estimate the pressure and other parameters of mineral formation from the microthermometric data of fluid inclusion study, we used the AqSo_NaCl software [21].

\section{Results}

Detailed mineralogical studies reveal the varieties of native gold and the minerals in the intergrowths with it from the Ludnaya and Slavnaya ore zones of the Chudnoe Au-PdREE deposit. Native gold is intergrown with one up to five minerals. The intergrowths of native gold with minerals are common. In the subsections below, we describe the features of the revealed varieties of native gold and minerals in the intergrowths with it from two ore zones.

\subsection{Native Gold in Rhyolites from the Ludnaya Ore Zone}

Figure 2 shows the macrophotograph of a polished section of typical rhyolite from the Ludnaya zone (a) and micrographs (b,c) of its fragment (p.1) with a fuchsite veinlet containing native gold. The sizes of gold particles vary from barely discernible 0.1 to $70-100 \mu \mathrm{m}$. Small gold particles are virtually of isometric shape, occasionally with elements 
of faceting, whereas larger individuals are of elongated interstitial shape. Figures 3-5 show the reflected light microscopy image (Figures 3a and 4a), BSE micrographs (Figure 5a,b), multi-layered colorful EDS maps (Figures $3 b$ and $4 b$ ), and maps of areal distribution of elements in characteristic rays (Figures $3 c-i$ and $4 c-g$ ) of fragments (p.1a, p.1b) with gold particles of various morphologies and sizes (Figure $2 b$ ). The gold particles have a homogeneous texture, which is clearly seen from these figures.

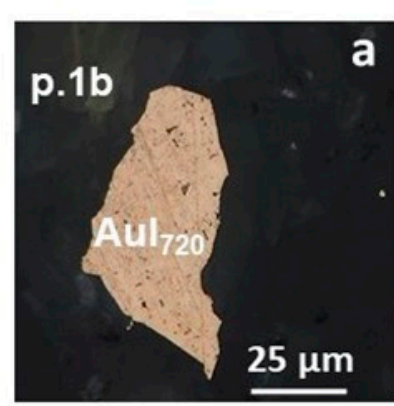

$\mathrm{Ag} \mathrm{L}$
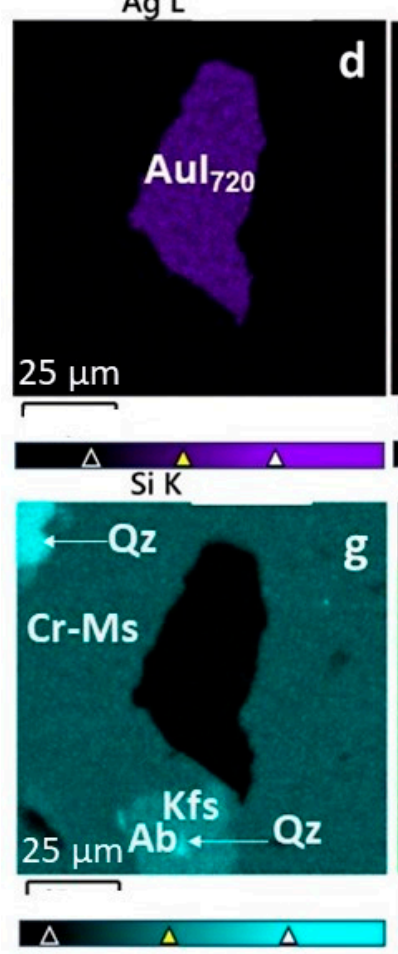

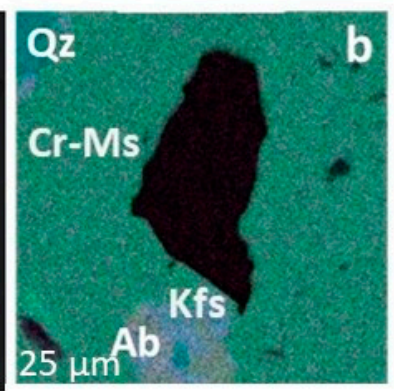

$\mathrm{Na} \mathrm{K}$

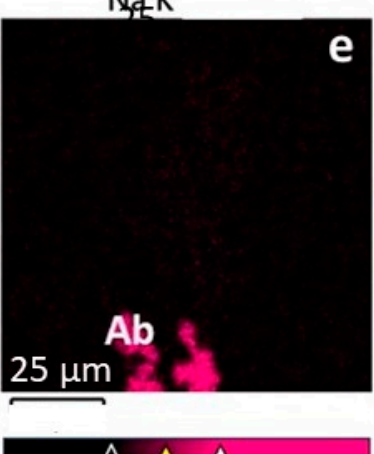

Al K

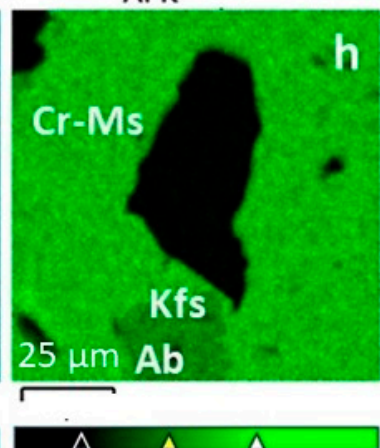

Au M

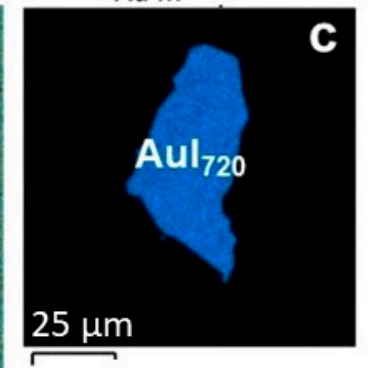

KK
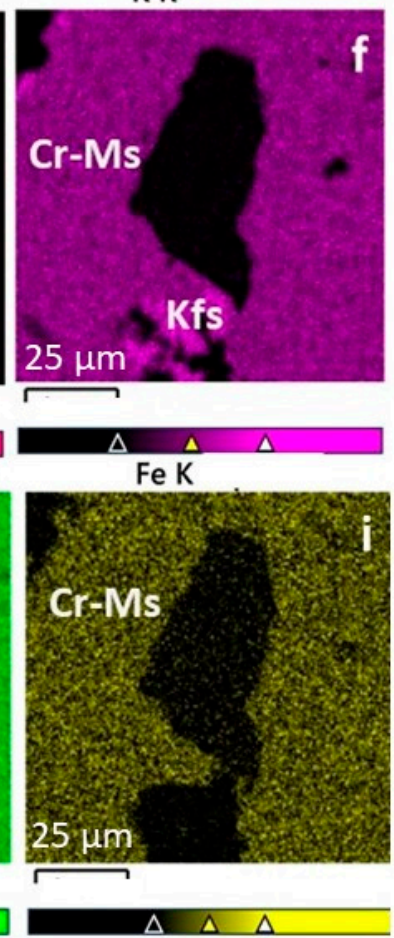

Figure 3. Native gold (type I) (AuI) (fineness 720\%, Ag impurity) in intergrowth with fuchsite (Cr-Ms) in rhyolite from the Ludnaya zone (Figure $2 b-p .1 b)$. (a)—reflected light microscopy image, (b) - multi-layered colorful EDS map, (c-i) - maps of areal distribution of elements in characteristic rays. Abbreviations of minerals: quartz (Qz), albite (Ab), K-feldspar (Kfs).

It is well seen on the multi-layered colorful EDS maps (Figures $3 b$ and $4 b$ ) and maps of areal distribution of elements ( $\mathrm{Au}, \mathrm{Ag}, \mathrm{Pd}, \mathrm{Na}, \mathrm{K}, \mathrm{Si}, \mathrm{Al}, \mathrm{Fe}, \mathrm{Sb}, \mathrm{As})$ in characteristic rays (Figures $3 \mathrm{c}-\mathrm{i}$ and $4 \mathrm{c}-\mathrm{g}$ ) that native gold in the analyzed fragments-points p.1a and p. $1 \mathrm{~b}$ - is localized in the interstices of fuchsite and has no common borders with quartz, albite, and K-feldspar. Figure 4 demonstrates that native gold (p.1a) is intergrown with fuchsite and mertieite. Mertieite also occurs as separate particles in fuchsite (Figure 4a). 

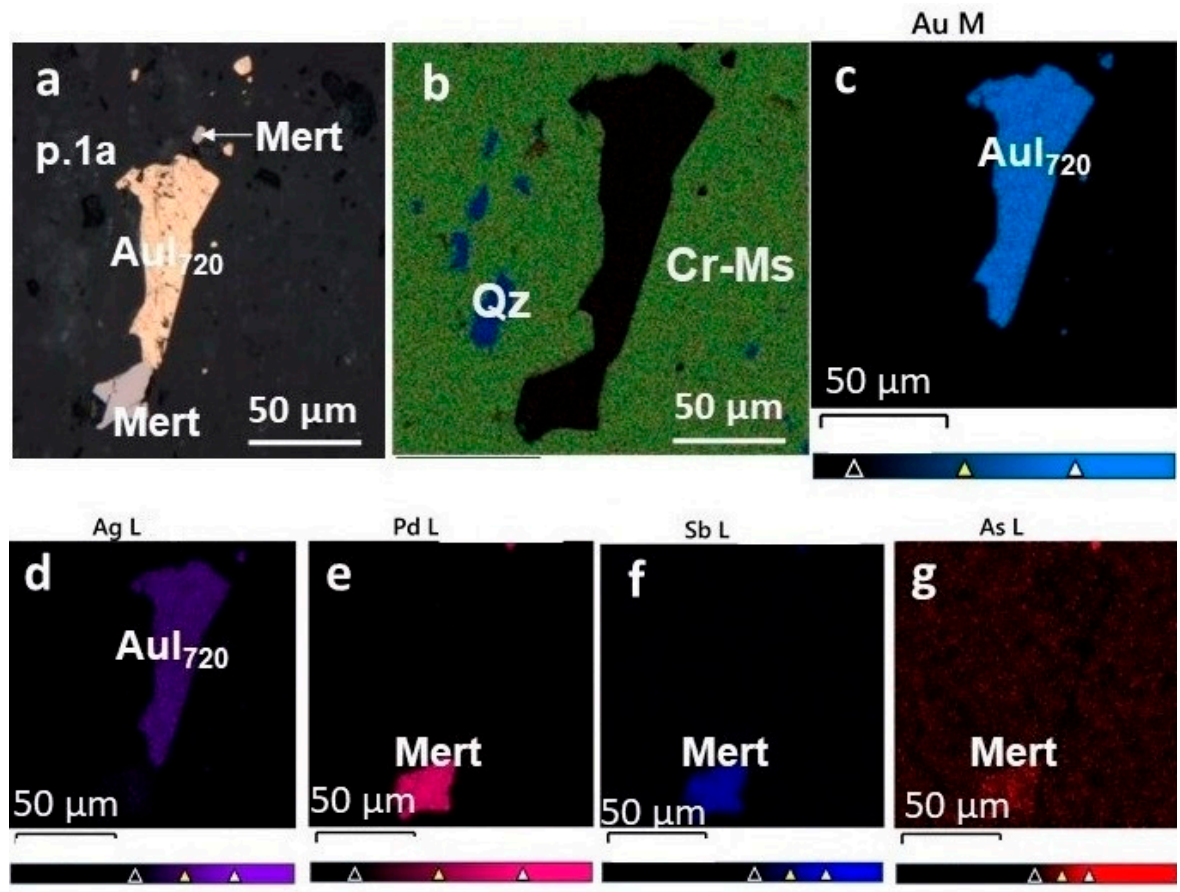

Figure 4. Native gold (type I) (AuI) (fineness $720 \%$, Ag impurity) in intergrowth with fuchsite (CrMs) and mertieite (Mert) (b-d) in rhyolite from the Ludnaya zone (Figure 2b-p.1a). (a)—reflected light microscopy image, (b)—multi-layered colorful EDS map, (c-g)—maps of areal distribution of elements in characteristic rays.

Figure $5 a, b$ shows relatively small particles of native gold (type I) (Figure $2 b-p .1 c$ ), surrounded by fuchsite or allanite. Allanite is localized in the axial part of the fuchsite veinlet (Figures $2 c$ and $5 a$ ). It is seen from Figure $5 b$ that one of the gold particles is intergrown with mertieite and allanite, and between allanite and fuchsite there are aggregates of quartz and K-feldspar, which also proves the absence of joint boundaries of native gold (type 1) with these minerals in rhyolite.
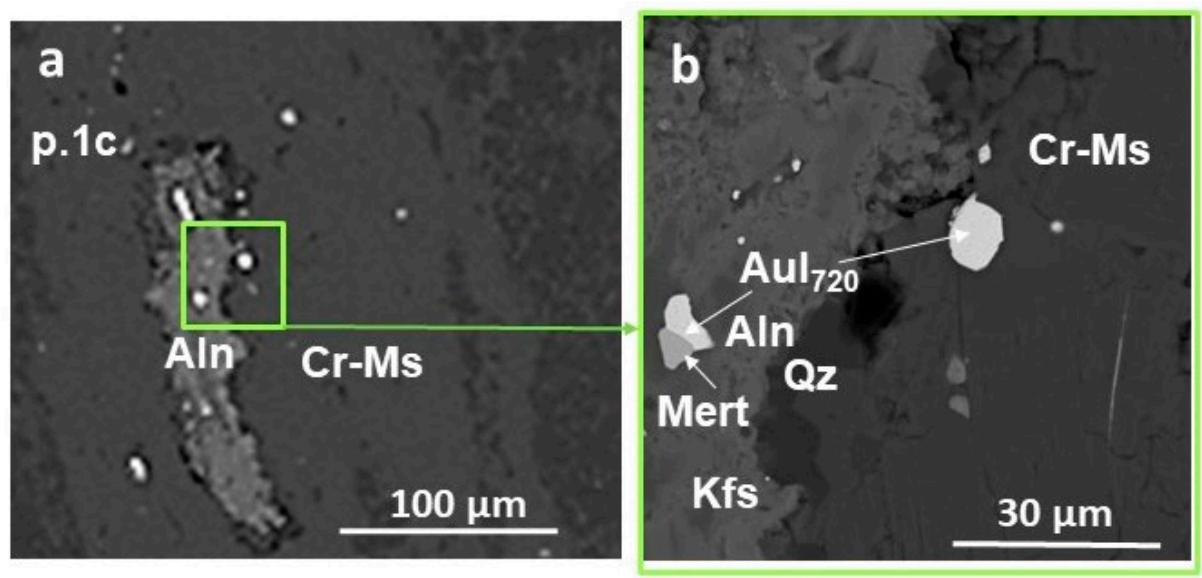

Figure 5. BSE micrographs of a fuchsite (Cr-Ms) vein with allanite (Aln), native gold (type I) (AuI) (Figure $2 \mathrm{~b}-\mathrm{p} .1 \mathrm{c}$ ) and other minerals in rhyolite from the Ludnaya zone (a) and its enlarged fragment (b): on the right are gold microparticles in intergrowth with fuchsite, on the left, in intergrowth with allanite (Aln) and mertieite (Mert). Abbreviations of minerals: quartz (Qz), K-feldspar (Kfs).

Native gold (type I) in intergrowth with fuchsite, allanite, and mertieite in green veinlets of rhyolite sample No.1 from the Ludnaya ore zone (Figure 2a) has a constant composition and major Ag impurity (fineness $716-724 \%, \mathrm{~N}_{\mathrm{Au}}=\mathrm{Au} * 1000 /(\mathrm{Au}+\mathrm{Ag})$ ) 
(Table 2). It is worth noting that $\mathrm{Pd}, \mathrm{Cu}, \mathrm{Hg}$, and other elements were not detected even when the acquisition time of the spectra was increased to $120 \mathrm{~s}$.

Table 2. Representative analyses of native gold (type I) and minerals in intergrowth with it in rhyolite No.1 (Figures 2-5) from the Ludnaya ore zone (EPMA data in wt.\% and formula).

\begin{tabular}{ccccccc}
\hline $\mathbf{N}$ & $\mathbf{A u}$ & $\mathbf{A g}$ & $\sum \mathbf{w t .} \%$ & $\mathbf{N}_{\mathrm{Au}}$ & Formula & Minerals in Intergrowth \\
\hline \multirow{2}{*}{ p.1a } & 69.54 & 27.6 & 97.14 & 716 & $\mathrm{Au}_{0.58} \mathrm{Ag}_{0.42}$ & $\mathrm{Cr}-\mathrm{Ms} ;$ U-Mert \\
& 70.52 & 27.22 & 97.74 & 722 & $\mathrm{Au}_{0.59} \mathrm{Ag}_{0.41}$ & $\mathrm{Cr}-\mathrm{Ms}$ \\
\hline \multirow{2}{*}{ p.1b } & 71.44 & 27.29 & 98.72 & 717 & $\mathrm{Au}_{0.58} \mathrm{Ag}_{0.42}$ & - - \\
& 70.52 & 27.22 & 97.74 & 724 & $\mathrm{Au}_{0.59} \mathrm{Ag}_{0.41}$ & $\mathrm{Cr}-\mathrm{Ms}$ \\
\multirow{2}{*}{ p.1c } & 69.91 & 27.12 & 97.03 & 720 & $\mathrm{Au}_{0.59} \mathrm{Ag}_{0.41}$ & $\mathrm{Aln;}$ Cu-Mert \\
\hline
\end{tabular}

Abbreviations of minerals: fuchsite (Cr-Ms), allanite (Aln) and U or Cu-mertieite (U- or Cu-Mert).

Fuchsite from the Ludnaya ore zone, in addition to $0.4-1.1 \mathrm{Cr}$, also contains $6.4-6.5 \mathrm{Fe}$, $0.3-0.6 \mathrm{Mg}$, and 0.2-0.3 $\mathrm{Ti}$ (in wt.\%). Its stoichiometric formula corresponds to $\mathrm{K}_{0.98} \mathrm{Fe}_{0.52}$ $\mathrm{Ti}_{0.02} \mathrm{Cr}_{0.01} \mathrm{Mg}_{0.09} \mathrm{Al}_{2.24} \mathrm{Si}_{3.24} \mathrm{O}_{11} \mathrm{H}_{4.5}$. Allanite has a varying composition with impurities of (in wt.\%): $0.1-0.3 \mathrm{Ce}$ and $\mathrm{Nd}$, up to $0.5 \mathrm{Pr}$, up to $0.1 \mathrm{La}, \mathrm{Sm}, \mathrm{Cr}$, and $\mathrm{Mn}\left(\mathrm{Ca}_{3.2-3.8} \mathrm{Fe}_{2-2.1} \mathrm{La}_{0-0.1}\right.$ $\mathrm{Ce}_{0-0.3} \mathrm{Nd}_{0-0.3} \mathrm{Pr}_{0-0.1} \mathrm{Mn}_{0.1} \mathrm{Cr}_{0-0.1} \mathrm{Al}_{3.9-4.1} \mathrm{Si}_{6.2} \mathrm{O}_{25} \mathrm{H}_{1.9}$ ). In some allanite crystals, we observed REE together with about 1 wt.\% Sr, which corresponds to $\left(\mathrm{Ca}_{4} \mathrm{Fe}_{2.1} \mathrm{Sr}_{0.1} \mathrm{La}_{0.1} \mathrm{Ce}_{0.3}\right.$ $\left.\mathrm{Nd}_{0.3} \mathrm{Pr}_{0.1} \mathrm{Sm}_{0.1} \mathrm{Al}_{4.1} \mathrm{Si}_{6.2} \mathrm{O}_{25} \mathrm{H}_{1.9}\right)$. The stoichiometric formula of palladium arsenoantimonide, according to IMA data, is similar to mertieite-II $\left(\mathrm{Pd}_{8} \mathrm{Sb}_{2.5} \mathrm{As}_{0.5}\right)$. The difference between mertieite-I and mertieite-II is chemical: mertieite-I $\operatorname{Pd}_{5+x}(\mathrm{Sb}, \mathrm{As})_{2-\mathrm{x}}(\mathrm{x}=0.1-0.2)$, mertieite-II $\mathrm{Pd}_{8} \mathrm{Sb}_{2.5} \mathrm{As}_{0.5}$. The stoichiometric formula of this phase in the fuchsite matrix is $\mathrm{Pd}_{7.7} \mathrm{Sb}_{2.6} \mathrm{As}_{0.6} \mathrm{U}_{0.1}$ (content of $\mathrm{U}$ impurity is about $2 \mathrm{wt} . \%$ ), and in the intergrowth with allanite it revealed higher contents of As, presence of $\mathrm{Cu}$, and absence of $\mathrm{U}: \mathrm{Pd}_{7.5} \mathrm{Cu}_{0.5} \mathrm{Sb}_{1.6} \mathrm{As}_{1.4}$.

Fuchsite veinlets also contain titanite $\mathrm{CaTiSiO}_{6}$ and $\mathrm{Y}$ mineral, which is similar in composition to keiviite $\left(\mathrm{Y}_{2} \mathrm{Si}_{2} \mathrm{O}_{7}\right)$. Rhyolite, in addition to quartz, albite, and K-feldspar, contains hematite (Figure 2a), less frequently, zircon and apatite. In zircon, hafnium (1-1.4 wt.\%) was present. Titanite was found to contain (in wt.\%): $1-1.2 \mathrm{Nb}, 0.3 \mathrm{Cr}$, and $0.9 \mathrm{Fe}$.

Results of studies showed that native gold of type I occurs in the form of individual particles or in intergrowth with mertieite-II in the allanite-fuchsite matrix in rhyolite from the Ludnaya ore zone and has direct contacts with these minerals, which suggests simultaneous formation of Au-Pd-REE mineralization and fuchsite veinlets and, probably, similar physicochemical conditions of deposition.

\subsection{Native Gold in Rhyolites from the Slavnaya Ore Zone}

Native gold in rhyolites from the Slavnaya ore zone, in contrast to the Ludnaya ore zone, along with silver contains copper, palladium, and mercury in various combinations and concentrations. The fineness of native gold $\left(\mathrm{N}_{\mathrm{Au}}, \%\right)$ was calculated using the equation: $\mathrm{Au}($ in wt.\%) $* 1000 /(\mathrm{Au}+\mathrm{Ag}+\mathrm{Cu}+\mathrm{Pd}+\mathrm{Hg}$ ) (in wt.\%). Depending on the set and contents of impurity elements in native gold, its reference symbols were adopted- $\mathrm{Au}\left(\mathrm{N}_{\mathrm{Au}}\right)_{\mathrm{AgCuPdHg}}$ (elements are given in order of decreasing concentrations). Several varieties of native gold were established (Tables 3-6): (1) Native gold with major content of $\mathrm{Ag}$ and minor $\mathrm{Cu}$ (fineness $860 \%$ ) (type II) (AuII $860 \mathrm{AgCu}$ ); (2) native gold with major $\mathrm{Ag}$ and insignificant amounts of $\mathrm{Cu}$ and Pd (fineness 830-890\%) (type III) (AuIII $830-890 \mathrm{AgCuPd}$ ); (3) native gold with major $\mathrm{Ag}$ and insignificant amounts of $\mathrm{Cu}, \mathrm{Pd}$, and $\mathrm{Hg}$ (fineness 830-860\% (type IV) $\left(\mathrm{AuIV}_{830-860 \mathrm{AgCuPdHg}}\right)$; (4) high-fineness gold (930-1000\%) with insignificant amounts of $\mathrm{Ag}, \mathrm{Cu}$, and (or) $\mathrm{Pd}$ (type $\mathrm{V})\left(\mathrm{AuV}_{930 \mathrm{AgCuPd}} \mathrm{AuV}\right)$, the total content of which does not exceed $7 \mathrm{wt} . \%$, or pure gold $(\mathrm{AuV})$. We found $\mathrm{Au}-\mathrm{Cu}$ intermetallides in association with native gold of types II-IV.

Results of study of the composition and amount of impurity elements in native gold and minerals in intergrowth with it in rhyolites from the Slavnaya ore zone are reported in the subsections below in the order of revealed varieties. 


\subsubsection{Native Gold with Ag and $\mathrm{Cu}$ Impurities}

Native gold containing major $\mathrm{Ag}$ and minor $\mathrm{Cu}$ (type II) was identified in two rhyolite samples from the Slavnaya ore zone No.2 (p.1a, 2, 6, 7) (Figure 6) and No.3 (p.1b, 1c, 3b, 3c, 4a) (Figure 7). Table 3 shows typical compositions of this type of native gold and provides a list of intergrown minerals.

In sample No.2 this native gold is localized in albite veins accompanying fuchsite veins (Figure 6a-c). It is intergrown with both minerals albite and fuchsite (Figure $6 \mathrm{c}, \mathrm{e}, \mathrm{g}, \mathrm{h}$ ) as well as with mertieite (Figure $6 \mathrm{~d}-\mathrm{g}$ ) and allanite (Figure $6 \mathrm{~g}, \mathrm{~h}$ ). As an example, Figure $6 \mathrm{~b}-\mathrm{j}$ shows optical and BSE micrographs of xenomorphic particles of native gold (type II) (20-40 $\mu \mathrm{m}$ in size) in intergrowth with albite, fuchsite, and mertieite (sample No.2, p.1a,6,7). The particles contain 11.4-12.7 wt.\% $\mathrm{Ag}$ and $1.5-1.8 \mathrm{wt} . \% \mathrm{Cu}$, which corresponds to the fineness $860-865 \%$ o (Table 3).

Table 3. Representative analyses of native gold (type II) and minerals in intergrowth with it in rhyolites from the Slavnaya ore zone (Nos. 2, 3, Figures 6 and 7) (EPMA data in wt.\% and formula).

\begin{tabular}{|c|c|c|c|c|c|c|c|}
\hline $\mathbf{N}$ & $\mathrm{Au}$ & Ag & $\mathrm{Cu}$ & $\sum w t . \%$ & $\mathbf{N}_{\mathrm{Au}}$ & Formula & Minerals in Intergrowth \\
\hline \multicolumn{8}{|c|}{ No.2 } \\
\hline p.1a & 85.03 & 11.58 & 1.72 & 98.34 & 865 & $\mathrm{Au}_{0.76} \mathrm{Ag}_{0.19} \mathrm{Cu}_{0.05}$ & Cr-Ms; Ab; Cu,Ag-Mert \\
\hline p.1a & 84.64 & 12.41 & 1.65 & 98.7 & 858 & $\mathrm{Au}_{0.76} \mathrm{Ag}_{0.19} \mathrm{Cu}_{0.05}$ & $-"-$ \\
\hline p.2 & 84.55 & 11.51 & 4.12 & 100.19 & 844 & $\mathrm{Au}_{0.71} \mathrm{Ag}_{0.18} \mathrm{Cu}_{0.11}$ & $\begin{array}{l}\text { Cr-Ms; Ab; Kfs; } \mathrm{AuCu} ; \\
\text { AuIII } \\
840-890\end{array}$ \\
\hline p.2 & 84.76 & 12.72 & 1.55 & 99.03 & 856 & $\mathrm{Au}_{0.75} \mathrm{Ag}_{0.21} \mathrm{Cu}_{0.04}$ & $-"$ - \\
\hline p.6 & 83.68 & 12.24 & 1.61 & 97.53 & 858 & $\mathrm{Au}_{0.75} \mathrm{Ag}_{0.20} \mathrm{Cu}_{0.04}$ & Cr-Ms; Ab; Aln; AuV $930-990$ \\
\hline p.6 & 83.78 & 12.19 & 1.77 & 97.73 & 857 & $\mathrm{Au}_{0.75} \mathrm{Ag}_{0.20} \mathrm{Cu}_{0.05}$ & $-"$ - \\
\hline p.7 & 85.38 & 11.44 & 1.48 & 98.3 & 869 & $\mathrm{Au}_{0.77} \mathrm{Ag}_{0.19} \mathrm{Cu}_{0.04}$ & $\begin{array}{c}\mathrm{Cr}-\mathrm{Ms} ; \mathrm{Ab} ; \mathrm{Cu}, \mathrm{Ag}, \mathrm{Au}-\mathrm{Mert} ; \\
\mathrm{AuV}_{990}\end{array}$ \\
\hline p.7 & 85.73 & 11.87 & 1.62 & 99.23 & 864 & $\mathrm{Au}_{0.77} \mathrm{Ag}_{0.19} \mathrm{Cu}_{0.04}$ & Cr-Ms; $\mathrm{Ab} ; \mathrm{AuV}_{990}$ \\
\hline p.7 & 85.67 & 12.28 & 1.54 & 99.48 & 861 & $\mathrm{Au}_{0.76} \mathrm{Ag}_{0.20} \mathrm{Cu}_{0.04}$ & $-"$ - \\
\hline p.7 & 84.41 & 12.38 & 1.4 & 98.19 & 860 & $\mathrm{Au}_{0.76} \mathrm{Ag}_{0.20} \mathrm{Cu}_{0.04}$ & Ms; $\mathrm{Ab} ; \mathrm{Aln} ; \mathrm{AuV}_{990}$ \\
\hline \multicolumn{8}{|c|}{ No.3 } \\
\hline p.1b & 85.22 & 11.86 & 1.88 & 98.96 & 861 & $\mathrm{Au}_{0.76} \mathrm{Ag}_{0.19} \mathrm{Cu}_{0.05}$ & $\begin{array}{c}\mathrm{Ab} ; \mathrm{Ms} ; \mathrm{Kfs} ; \mathrm{Qz} ; \mathrm{AuV}_{1000-970} \\
\mathrm{AuCu} ; \mathrm{X1}\end{array}$ \\
\hline p.1b & 84.93 & 11.95 & 2.04 & 98.92 & 859 & $\mathrm{Au}_{0.75} \mathrm{Ag}_{0.19} \mathrm{Cu}_{0.06}$ & $-"$ - \\
\hline p.1b & 84.21 & 12.57 & 1.51 & 98.29 & 857 & $\mathrm{Au}_{0.75} \mathrm{Ag}_{0.21} \mathrm{Cu}_{0.04}$ & $-"$ - \\
\hline p.1e & 83.62 & 11.75 & 4.64 & 100.01 & 836 & $\mathrm{Au}_{0.70} \mathrm{Ag}_{0.18} \mathrm{Cu}_{0.12}$ & $\mathrm{Ab} ; \mathrm{Kfs} ; \mathrm{Qz} ; \mathrm{AuIII}{ }_{840-890}$ \\
\hline p.2 & 86.84 & 12.83 & 2.24 & 101.9 & 852 & $\mathrm{Au}_{0.74} \mathrm{Ag}_{0.20} \mathrm{Cu}_{0.06}$ & $\mathrm{Ab} ; \mathrm{Ms} ; \mathrm{Qz}$ \\
\hline p. 2 & 84.57 & 12.9 & 2.11 & 99.58 & 849 & $\mathrm{Au}_{0.74} \mathrm{Ag}_{0.21} \mathrm{Cu}_{0.05}$ & $-"-$ \\
\hline p. 2 & 86.36 & 12.27 & 1.71 & 100.35 & 861 & $\mathrm{Au}_{0.76} \mathrm{Ag}_{0.20} \mathrm{Cu}_{0.05}$ & $-"$ - \\
\hline p. 2 & 85.39 & 12.98 & 2.02 & 100.39 & 851 & $\mathrm{Au}_{0.75} \mathrm{Ag}_{0.21} \mathrm{Cu}_{0.06}$ & $-"$ - \\
\hline p. 2 & 83.16 & 14.85 & 1.35 & 99.36 & 837 & $\mathrm{Au}_{0.73} \mathrm{Ag}_{0.23} \mathrm{Cu}_{0.04}$ & $-"$ - \\
\hline p.2 & 84.86 & 12.29 & 2.42 & 99.57 & 852 & $\mathrm{Au}_{0.73} \mathrm{Ag}_{0.20} \mathrm{Cu}_{0.07}$ & -“- \\
\hline p.3b & 84.13 & 12.21 & 1.67 & 98.01 & 858 & $\mathrm{Au}_{0.75} \mathrm{Ag}_{0.2} \mathrm{Cu}_{0.05}$ & $\mathrm{Ab} ; \mathrm{Ms}$ \\
\hline p.3c & 84.82 & 12.19 & 1.76 & 98.77 & 859 & $\mathrm{Au}_{0.75} \mathrm{Ag}_{0.2} \mathrm{Cu}_{0.05}$ & $\mathrm{Ab}$ \\
\hline p.4a & 84.54 & 12.33 & 1.93 & 98.81 & 856 & $\mathrm{Au}_{0.75} \mathrm{Ag}_{0.2} \mathrm{Cu}_{0.05}$ & $\mathrm{Ab} ; \mathrm{Kfs} ; \mathrm{Cu}-\mathrm{Mert} ; \mathrm{X} 1$ \\
\hline p.4a & 84.07 & 12.34 & 2.07 & 98.48 & 854 & $\mathrm{Au}_{0.74} \mathrm{Ag}_{0.2} \mathrm{Cu}_{0.06}$ & $-"-$ \\
\hline
\end{tabular}

Abbreviations of minerals: native gold of type II, III and V (AuII, AuIII and AuV), fuchsite (Cr-Ms), muscovite (Ms), allanite (Aln), quartz $(\mathrm{Qz})$, albite (Ab), K-feldspar (Kfs) Cu, $\mathrm{Ag}$, U-mertieite (Cu, Ag, U-Mert), tetra-auricupride ( $\mathrm{AuCu}$ ) and amoeba phase (X1).

Figure $6 \mathrm{~g}$ shows native gold of type II in the intergrowth with allanite, albite, fuchsite, and mertieite in the same sample No.2 (p.7). The contact between native gold and allanite is not resorbed, which suggests that they formed simultaneously. In some albite-fuchsite veinlets of sample No.2 (p.6) (Figure $6 \mathrm{~h}-\mathrm{j}$ ) gold particles in the marginal parts are replaced by higher-fineness gold (fineness 930-965\%) (type V): the content of Ag decreases to $2.2 \mathrm{wt.} \%$, and that of $\mathrm{Cu}$ increases to $2.3 \mathrm{wt} . \%$ and Pd appears (0.9-1.9 wt.\%) (Table 6). The texture of such native gold becomes porous (Figure 6j). The albite-fuchsite-allanite veinlet contains apatite inclusions $\left(\mathrm{Ca}_{4.9} \mathrm{P}_{2.82} \mathrm{O}_{12} \mathrm{~F}_{1}\right)$ (Figure $6 \mathrm{~h}$ ). 

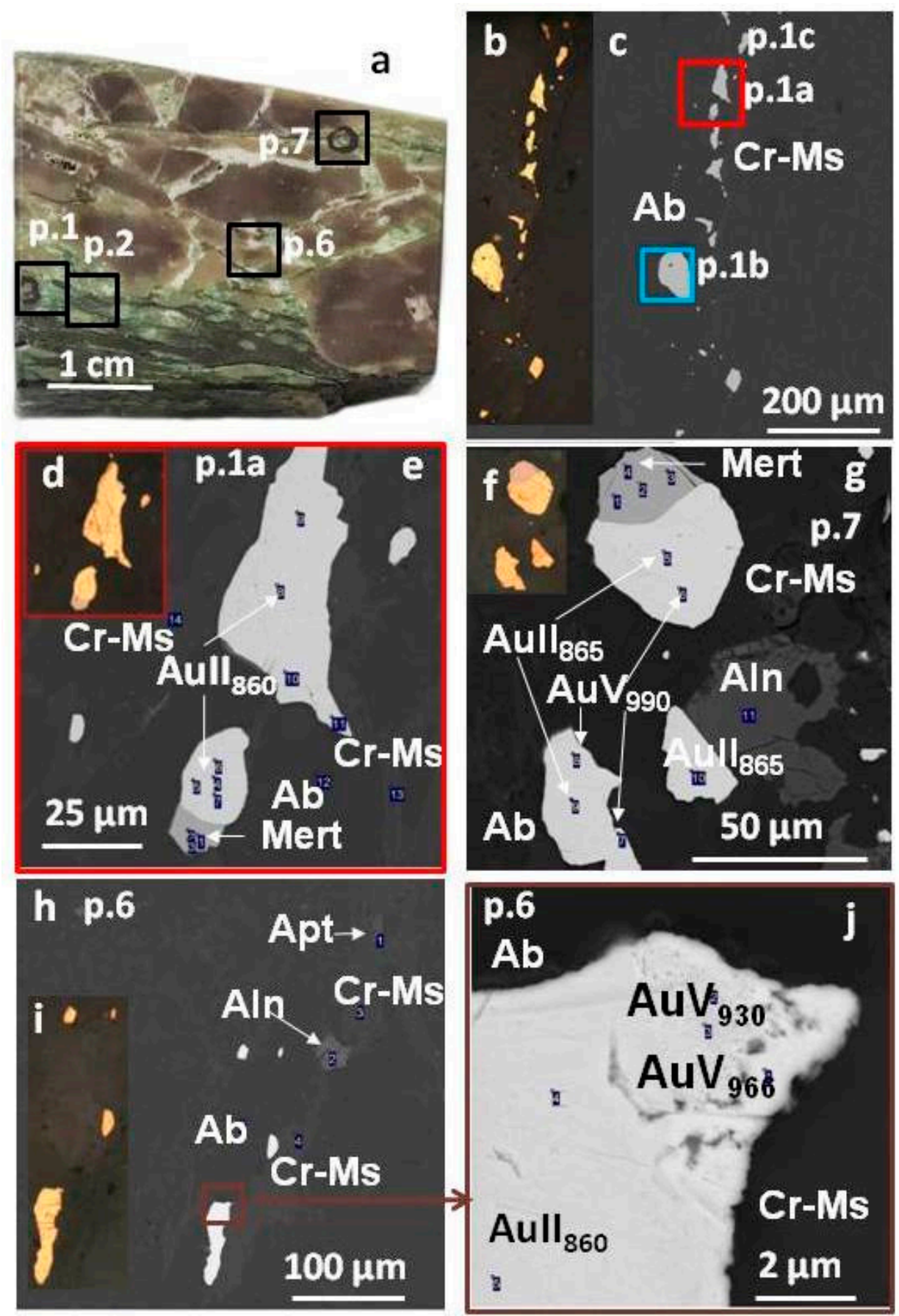

Figure 6. Macrophotograph of a polished section of rhyolite No.2 from the Slavnaya ore zone (a) with albite-fuchsite veins and its fragments with native gold (types II, V) (p.1,2,6,7) (b-j). (b b,d,f,i) Reflected light microscopy image; (c,e,g,h, $\mathbf{j})$ BSE micrographs. (j) Enlarged fragment on h. Abbreviations of minerals: native gold (type II, V) (AuII, AuV), fuchsite (Cr-Ms), allanite (Aln), albite (Ab), apatite (Apt), mertieite (Mert).

In sample No.3 (Figure 7a), native gold of type II is concentrated in albite veinlets with rare fragments of fuchsite and it is intergrown with albite (p.3c) or albite and fuchsite (p.3b) (Figure 7b) or albite, fuchsite, and mertieite (p.4a) (Figure 7c) or albite, fuchsite, quartz, and K-feldspar (p.1b,1c) (Figure 7d,f). It is localized in the monomineral albite matrix (sample No.3, p.3c) or bimineral albite-fuchsite matrix (sample No.3, p.3b) (Figure 7b), it is homogeneous and contains 11.5-12.8 wt.\% Ag and 1.5-2.4 wt.\% Cu, its fineness is $860 \%$ (Table 3). 

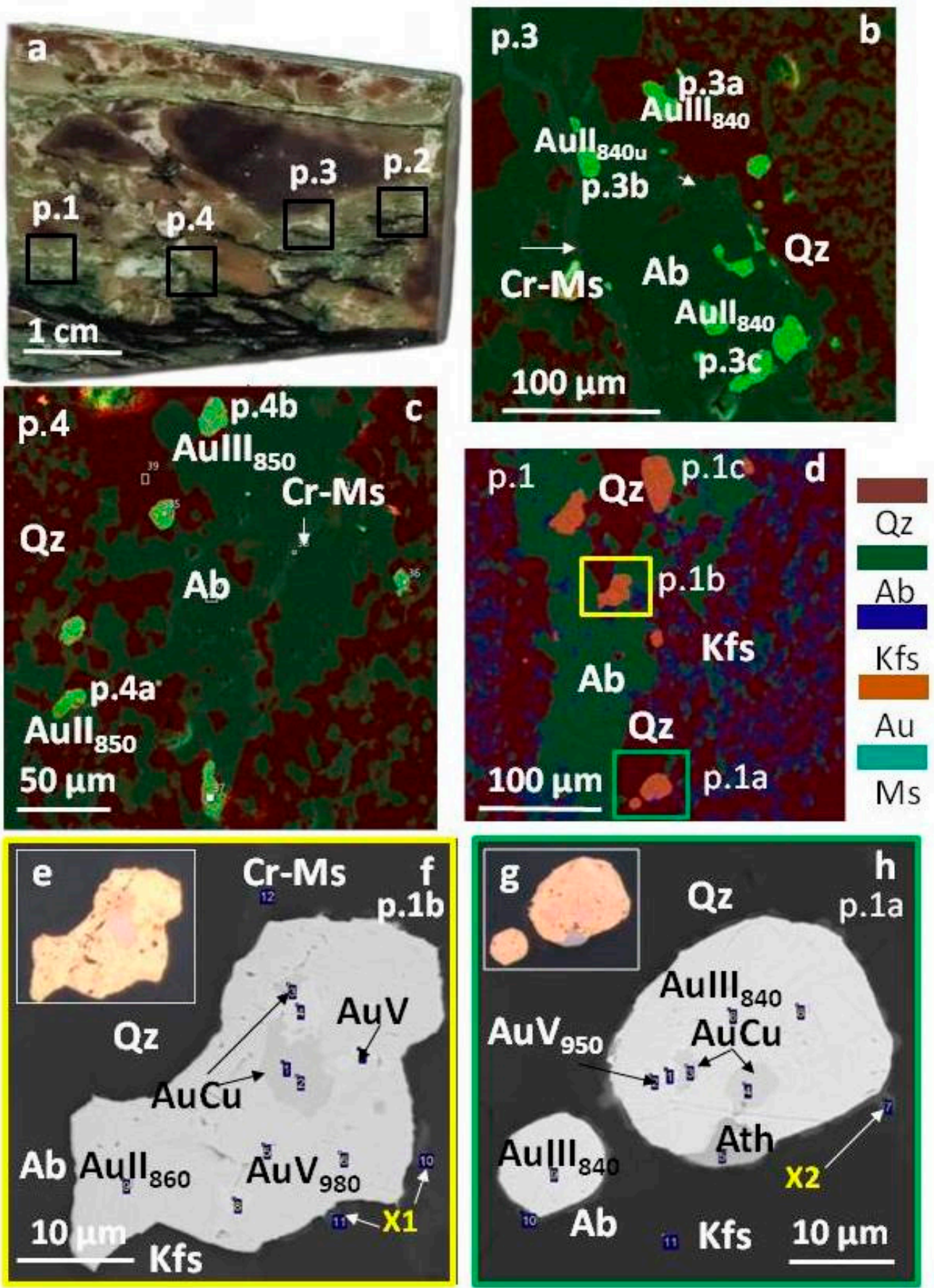

Figure 7. Macrophotograph of a polished section of rhyolite No.3 from the Slavnaya ore zone (a), multi-layered colorful EDS maps of its fragments (p.3,4,1) (b-d), reflected light microscopy image $(\mathbf{e}, \mathbf{g})$ and BSE micrographs (f,h) of native gold (types II, III, V, AuCu) in intergrowth with quartz (Qz), albite (Ab), fuchsite (Cr-Ms), K-feldspar (Kfs), amoeba phase (X1) (f) (p.1b) or with quartz, albite, atheneite (Atn) and amoeba phase (X2) (h) (p.1a). Abbreviations of minerals: native gold (type II, III, V) (AuII, AuIII, AuV), tetra-auricupride ( $\mathrm{AuCu})$.

Native gold of type II in the polymineral matrix p.1b (sample No.3) (Figure 7d), consisting of albite, fuchsite, quartz, and K-feldspar, has a heterogenous texture (Figure 7f). It contains isometric inclusions (to $10 \times 12 \mu \mathrm{m}^{2}$ in size) of tetra-aucupride with trace concentrations of $\mathrm{Pd}(0.9 \mathrm{wt} . \%)\left(\mathrm{Au}_{1.07} \mathrm{Cu}_{0.91} \mathrm{Pd}_{0.02}\right)$ (III type) (Table 7), and microinclusions of higher-fineness (fineness $980 \%$, with trace contents of $\mathrm{Cu}, \mathrm{Ag}$, no $\mathrm{Pd}$ ) or pure gold 
(fineness $1000 \%$, without impurities) (type V) (Table 6). In most gold particles the content of $\mathrm{Cu}$ is $1.9-2.0 \mathrm{wt} . \%$ and that of $\mathrm{Ag}$ is $11.9-12.6 \mathrm{wt} . \%$, which corresponds to fineness $860 \%$. In the marginal parts of these gold particles one can observe amoeboid-like rims. The chemical composition of these rims is similar to the mixture of albite with the $\mathrm{X} 1$ phase, containing, along with main elements $\mathrm{Na}, \mathrm{Al}, \mathrm{Si}$, and $\mathrm{O}$, impurities of $\mathrm{Y}(2.1), \mathrm{Zr}(2.8), \mathrm{Ce}$ (0.6), U (1.3), Fe (0.2), and As (0.9) (in wt.\%) (Figure 7f, p.1b).

The stoichiometric formula of palladium arsenoantimonide, according to IMA data, is similar to mertieite-II, but contains $5.5 \mathrm{wt} . \% \mathrm{Cu}$ (No.3, p.4a) or $5.1-5.4 \mathrm{wt} . \% \mathrm{Cu}$ and $0.7-0.9$ wt.\% Ag (No.2, p.1a), and occasionally Au too (No.2, p.7): 2.6-2.9 Cu; 0-0.8 Ag, 1.3-2.7 $\mathrm{Au}$ (in wt.\%). This phase has elements of faceting. The boundaries between the particles of mertieite-II and native gold of type II are straight. Fuchsite contains the following impurities (in wt.\%): $1.1-1.7 \mathrm{Cr}$, 4.6-5.7 Fe, $0.2 \mathrm{Ti}, 0.5-0.8 \mathrm{Mg}$, $0.8 \mathrm{Mn}$, and 0.3 Ba.

\subsubsection{Native Gold with $\mathrm{Ag}$, $\mathrm{Cu}$, and $\mathrm{Pd}$ Impurities}

Native gold containing major $\mathrm{Ag}$, minor $\mathrm{Cu}$, and trace Pd impurities (type III) (Table 4) was found in rhyolite samples Nos. 3 (Figure 7a, p.1,3,4) and 4 (Figure 8a, p.2).
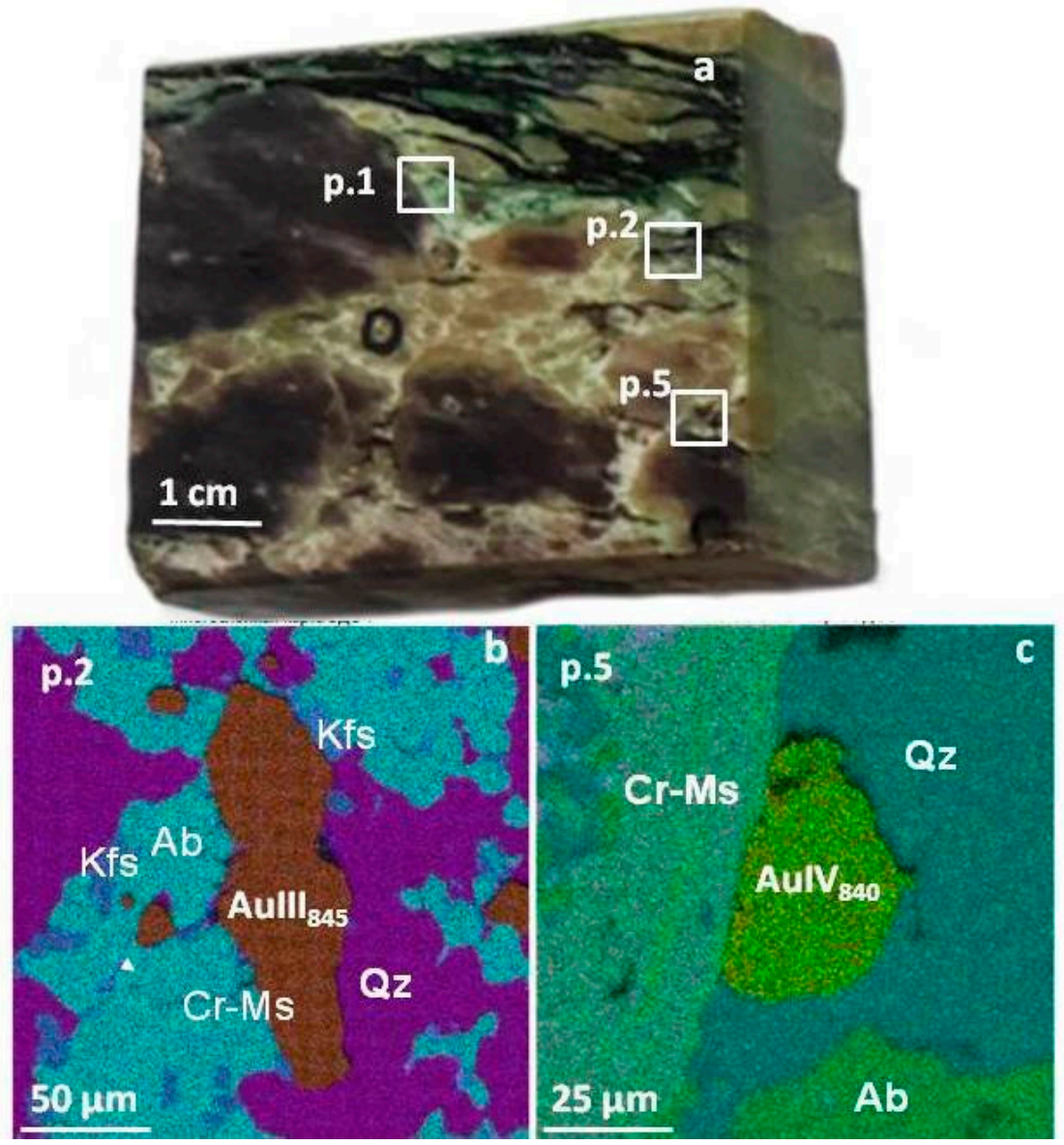

Figure 8. Macrophotograph of a polished section of rhyolite No.4 from the Slavnaya ore zone (a) and multi-layered colorful EDS maps of its fragments (p.2 and p.5) (b,c) with native gold (types III- $\mathbf{b}$, IV—c) in poly-(b) and bimineral (c) matrices: (b) Quartz, albite, K- feldspar, fuchsite; (c) Quartz, fuchsite. Abbreviations of minerals: native gold (type III, IV) (AuIII, AuIV), fuchsite (Cr-Ms), quartz (Qz), albite (Ab), K-feldspar (Kfs).

In sample No.3 (Figure 7a), the minerals intergrown with gold particles are quartz, albite, and K-feldspar (p.3a, 4b-Figure 7b,c), (p.1c-Figure 7d-f), (p.1a-Figure 7g,h). Native gold of type III (grains of 50-70 $\mu \mathrm{m}$ in size), surrounded mainly by quartz, occasionally occurs in contact with albite and K-feldspar (sample No.3, p.1a) (Figure 7d,h), contains (in 
wt.\%): 12.8-13.1 Ag, 1.8-2.2 Cu, 0.7-1.0 Pd, and its fineness varies in a narrow range of $840-860 \%$ o (Table 4 ).

Table 4. Representative analyses of native gold (type III) and minerals in intergrowth with it in rhyolites from Slavnaya ore zone (Nos. 3, 4-Figures 7a and 8a) (EPMA data in wt.\% and formula).

\begin{tabular}{|c|c|c|c|c|c|c|c|c|}
\hline $\mathbf{N}$ & $\mathrm{Au}$ & Ag & $\mathrm{Cu}$ & $\mathbf{P d}$ & $\sum w t . \%$ & $\mathbf{N}_{\mathrm{Au}}$ & Formula & Minerals in Intergrowth \\
\hline \multicolumn{9}{|c|}{ No.3 } \\
\hline p.1a & 83.35 & 12.76 & 1.92 & 0.96 & 98.98 & 842 & $\mathrm{Au}_{0.73} \mathrm{Ag}_{0.20} \mathrm{Cu}_{0.06} \mathrm{Pd}_{0.01}$ & $\mathrm{Qz} ; \mathrm{Ab} ; \mathrm{Kfs} ; \mathrm{Ath} ; \mathrm{AuCu} ; \mathrm{AuV}_{950} ; \mathrm{X} 2$ \\
\hline p.1a & 83.46 & 13.05 & 2.21 & 0.67 & 99.39 & 840 & $\mathrm{Au}_{0.72} \mathrm{Ag}_{0.21} \mathrm{Cu}_{0.06} \mathrm{Pd}_{0.01}$ & $-"-$ \\
\hline p.1c & 82.71 & 7.77 & 6.46 & 1.01 & 97.96 & 844 & $\mathrm{Au}_{0.70} \mathrm{Ag}_{0.12} \mathrm{Cu}_{0.16} \mathrm{Pd}_{0.02}$ & $\mathrm{Qz} ; \mathrm{Ab} ; \mathrm{Kfs} ; \mathrm{X} 2$ \\
\hline p.1c & 84.79 & 12.9 & 1.92 & 0.47 & 100.08 & 847 & $\mathrm{Au}_{0.74} \mathrm{Ag}_{0.20} \mathrm{Cu}_{0.05} \mathrm{Pd}_{0.01}$ & $-"-$ \\
\hline p.1c & 84.63 & 12.56 & 2.05 & 1.03 & 100.28 & 844 & $\mathrm{Au}_{0.73} \mathrm{Ag}_{0.20} \mathrm{Cu}_{0.05} \mathrm{Pd}_{0.02}$ & $-"$ \\
\hline p.1c & 89.11 & 9.17 & 1.15 & 1.14 & 100.56 & 886 & $\mathrm{Au}_{0.80} \mathrm{Ag}_{0.15} \mathrm{Cu}_{0.03} \mathrm{Pd}_{0.02}$ & $-"$ - \\
\hline p.1c & 84.5 & 12.37 & 2.46 & 0.88 & 100.21 & 843 & $\mathrm{Au}_{0.73} \mathrm{Ag}_{0.19} \mathrm{Cu}_{0.07} \mathrm{Pd}_{0.01}$ & $-"-$ \\
\hline p.3a & 83.87 & 12.46 & 1.76 & 0.62 & 98.71 & 850 & $\mathrm{Au}_{0.74} \mathrm{Ag}_{0.2} \mathrm{Cu}_{0.05} \mathrm{Pd}_{0.02}$ & $\mathrm{Qz} ; \mathrm{Ab} ; \mathrm{Cr}-\mathrm{Ms} ; \mathrm{Ath} ; \mathrm{AuV}_{930}$ \\
\hline p.3a & 83.93 & 12.73 & 1.61 & 0.57 & 98.84 & 849 & $\mathrm{Au}_{0.73} \mathrm{Ag}_{0.21} \mathrm{Cu}_{0.05} \mathrm{Pd}_{0.02}$ & $-"$ - \\
\hline p.3a & 82.19 & 8.88 & 7.64 & 0.41 & 99.12 & 829 & $\mathrm{Au}_{0.67} \mathrm{Ag}_{0.13} \mathrm{Cu}_{0.19} \mathrm{Pd}_{0.01}$ & $-"$ \\
\hline p. $4 b$ & 82.42 & 8.43 & 7.24 & 1.2 & 99.3 & 830 & $\mathrm{Au}_{0.67} \mathrm{Ag}_{0.13} \mathrm{Cu}_{0.18} \mathrm{Pd}_{0.02}$ & $\mathrm{Qz} ; \mathrm{Ab} ; \mathrm{Kfs}$ \\
\hline p. $4 b$ & 82.6 & 12.81 & 1.9 & 0.98 & 98.29 & 840 & $\mathrm{Au}_{0.73} \mathrm{Ag}_{0.21} \mathrm{Cu}_{0.05} \mathrm{Pd}_{0.02}$ & $-"$ \\
\hline p. $4 b$ & 82.03 & 13.41 & 1.54 & 1.11 & 98.09 & 836 & $\mathrm{Au}_{0.73} \mathrm{Ag}_{0.21} \mathrm{Cu}_{0.05} \mathrm{Pd}_{0.02}$ & $-"$ - \\
\hline \multicolumn{9}{|c|}{ No.4 } \\
\hline p. 2 & 83.64 & 12.3 & 2.16 & 1.14 & 99.24 & 843 & $\mathrm{Au}_{0.74} \mathrm{Ag}_{0.2} \mathrm{Cu}_{0.06} \mathrm{Pd}_{0.02}$ & $\mathrm{Qz} ; \mathrm{Ab} ; \mathrm{Kfs} ; \mathrm{Cr}-\mathrm{Ms}$ \\
\hline p. 2 & 83.64 & 11.97 & 1.41 & 0.75 & 97.78 & 855 & $\mathrm{Au}_{0.75} \mathrm{Ag}_{0.2} \mathrm{Cu}_{0.04} \mathrm{Pd}_{0.01}$ & $-“-$ \\
\hline p. 2 & 82.57 & 11.21 & 3.05 & 1.2 & 98.03 & 842 & $\mathrm{Au}_{0.73} \mathrm{Ag}_{0.19} \mathrm{Cu}_{0.06} \mathrm{Pd}_{0.02}$ & $-"$ - \\
\hline p.2 & 84.02 & 11.18 & 2.69 & 1.07 & 98.96 & 849 & $\mathrm{Au}_{0.73} \mathrm{Ag}_{0.18} \mathrm{Cu}_{0.07} \mathrm{Pd}_{0.02}$ & $-"$ - \\
\hline
\end{tabular}

Abbreviations of minerals: native gold (type II, V) (AuII, AuV), fuchsite (Cr-Ms), quartz (Qz), albite (Ab), K-feldspar (Kfs), atheneite (Atn), tetra-aucupride $(\mathrm{AuCu})$ and amoeba phase $(\mathrm{X} 2)$.

Native gold III is heterogeneous in texture (Figure 7h) and contains microveinlets and microinclusions of higher fineness gold $(950 \%$ ) (Table 6) and idiomorphic inclusions of tetra-auricupride (to 10-20 $\mu \mathrm{m}$ in size) of composition $\mathrm{Au}_{1.06} \mathrm{Cu}_{0.92} \mathrm{Pd}_{0.03}(0.7-1.1 \mathrm{wt} . \% \mathrm{Pd}$ ) (Table 7). In high-fineness gold, the amount of impurities of $\mathrm{Cu}$ increases to $2.3-2.8 \mathrm{wt} . \%$ and that of $\mathrm{Pd}$, to 2.2-2.4 wt.\%, whereas the content of Ag decreases up to complete disappearance $(<0.4 \mathrm{wt} . \%)$. The marginal parts of the intergrowth with native gold of type III contain atheneite (Figure $7 \mathrm{~h}, \mathrm{p} .1 \mathrm{a}$ ). The atheneite composition $\mathrm{Pd}_{2.62} \mathrm{As}_{0.93} \mathrm{Hg}_{0.29}$ differs from the ideal stoichiometric formula $\mathrm{Pd}_{2}\left(\mathrm{As}_{0.75} \mathrm{Hg}_{0.25}\right)$ in the higher contents of $\mathrm{Pd}$ and As. Native gold of type III is frequently surrounded by thin amoeba-shaped rims (Figure 7h, p.1a). The composition of rim substance (phase X2) was not identified. Most likely, this is a mixture of phases (quartz $+\mathrm{X} 2$ ) because, in addition to major elements $\mathrm{Si}$ and $\mathrm{O}$, it also contains such elements as Y (3.2), Zr (2.4), Th (1.3), Ce (0.9) (in wt.\%) etc.

Native gold of type III in association with quartz, albite, and K-feldspar (p.1c) (Figure 7d), (p.3a) (Figure 7b) and (p.4b) (Figure 7c) of sample No.3 is characterized by a wider range of the contents of elements (in wt.\%): from 7.8 to $12.9 \mathrm{Ag}$ and 1.1 to $7.6 \mathrm{Cu}$, with the same amount of $\mathrm{Pd}(0.4-1.2)$, which corresponds to the fineness of $830-890 \%$ (Table 4 ). The elevated concentrations of $\mathrm{Cu}$ (to $6.5^{*} \mathrm{wt} . \%$, Table 4 ) are, most likely, due to the presence of the $\mathrm{AuCu}$ phase. In native gold of type III we found microinclusions of higher-fineness gold $(930-960 \%)$ : the content of Ag decreases down to complete disappearance, $\mathrm{Cu}$ is 1.2 wt. \%, and Pd increases to 2.8 wt.\% (Table 6).

In sample No.4 (p.2) (Figure 8a) naive gold of type III is mainly surrounded by quartz and albite and occasionally has the contact with K-feldspar and fuchsite (Figure 8b). Its fineness is $840-850 \%$, the contents of elements vary (in wt.\%): $11.2-12.3 \mathrm{Ag}, 1.4-3.1 \mathrm{Cu}$ and 0.8-1.2 Pd (Table 4). 
In native gold of type III, the amount of elements is not higher than $13.4 \mathrm{wt} . \%$ for $\mathrm{Ag}$, 9.6 wt. \% Cu and 1.2 wt.\% Pd (Table 4). The elevated contents of $\mathrm{Cu}$ in native gold of type III can be related to the presence of $\mathrm{Au}-\mathrm{Cu}$ intermetallide in the point probe.

\subsubsection{Native Gold with $\mathrm{Ag}, \mathrm{Cu}, \mathrm{Pd}$, and $\mathrm{Hg}$ Impurities}

Native gold of type IV with four elements $\mathrm{Ag}, \mathrm{Cu}, \mathrm{Pd}$, and $\mathrm{Hg}$ was found in rhyolite sample No.4 (p.1, 5) (Figure 8a,c and Figure 9a). Gold particles are in intergrowth with quartz, albite, and K-feldspar (Figure 9b, p.1) or quartz and fuchsite (Figure 8c). Figure 9a,f show discernible lattice decay structures with tetra-auricupride. The contents of the following elements in this native gold are (in wt.\%): 11.9-12.5 Ag, 1.7-2.5 Cu, 0.6-0.8 Pd, and $0.7-1 \mathrm{Hg}$ (Table 5). Its fineness varies in the range of 840-870\%. Variations in copper concentrations are likely due to the presence of platelets of $\mathrm{AuCu}$ phase. In native gold of type IV there are inclusions of U-mertieite-II (Figure 9e) and microinclusions of highfineness gold (type V) (Figure 9a).
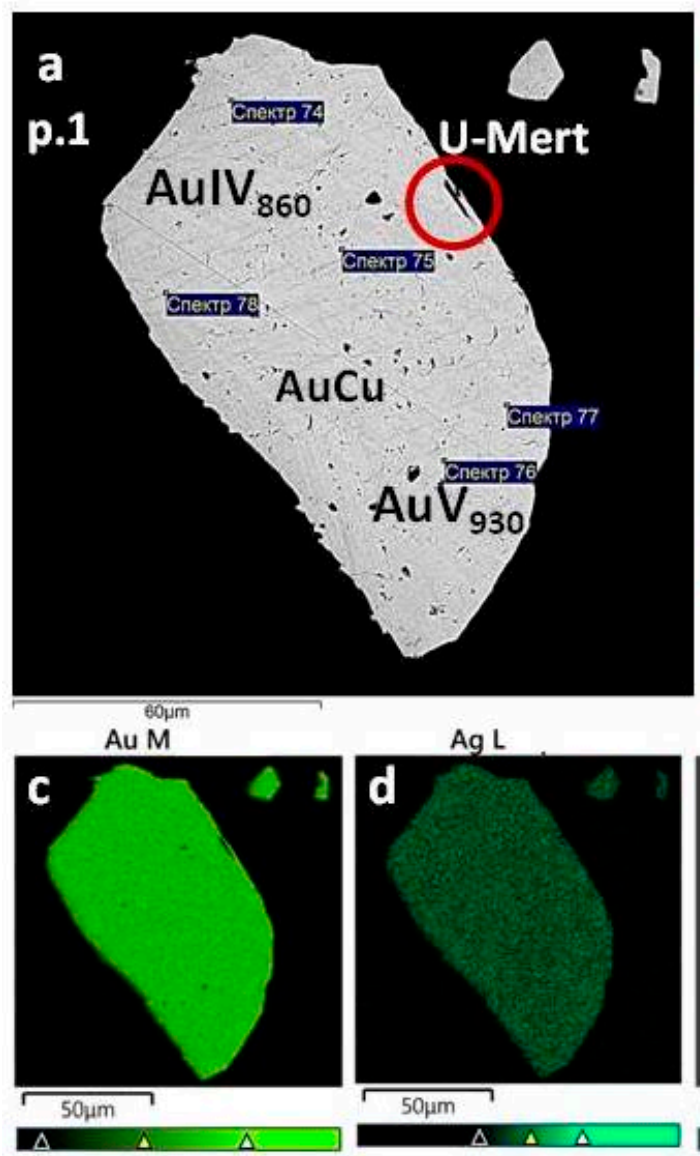

$\mathrm{Ag} \mathrm{L}$

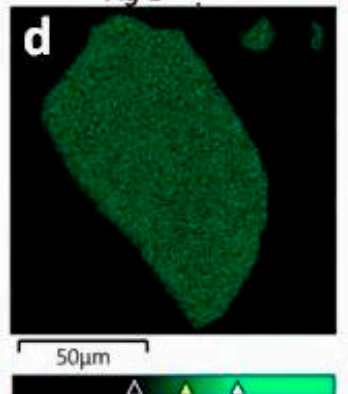

Si K

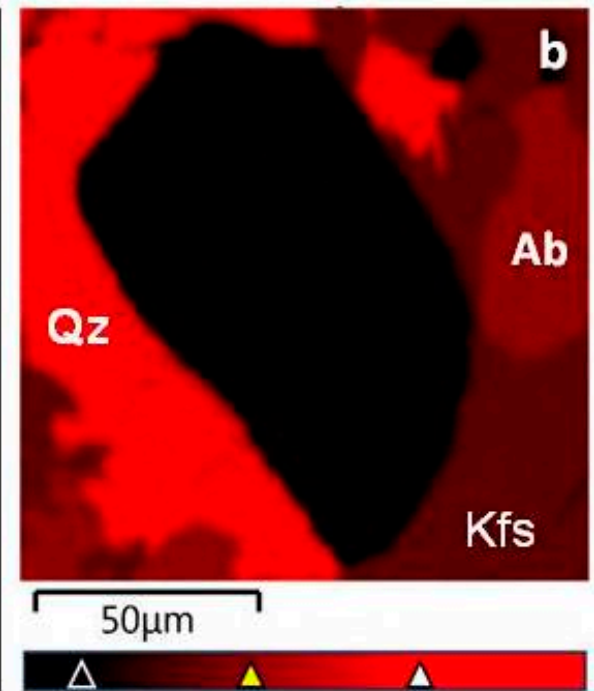

Cu L

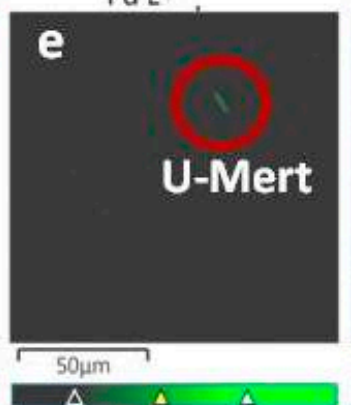

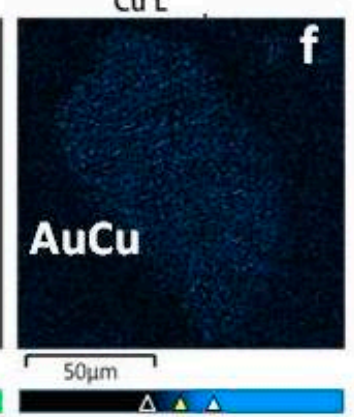

Figure 9. Native gold of type IV with decay structures (matrix-fineness $860 \%$, AuCu platelets) and inclusions of higher-fineness gold (type V) and mertieite (with U impurity) in the quartzalbite-K-feldspar vein of rhyolite (No.4, p. 1) (Figure 8a): (a) BSE micrograph; (b-f) maps of areal distribution elements $(\mathrm{Si}, \mathrm{Au}, \mathrm{Ag}, \mathrm{Pd}, \mathrm{Cu})$ in characteristic rays. Abbreviations of minerals: native gold of type IV and V (AuIV, AuV), quartz (Qz), albite (Ab), K-feldspar (Kfs), U-mertieite (U-Mert), tetra-auricupride $(\mathrm{AuCu})$. 
Table 5. Representative analyses of native gold (type IV) and minerals in intergrowth with it in rhyolite from the Slavnaya ore zone (No.4; Figure 8a) (EPMA data in wt.\% and formula).

\begin{tabular}{|c|c|c|c|c|c|c|c|c|c|}
\hline $\mathbf{N}$ & $\mathrm{Au}$ & Ag & $\mathrm{Cu}$ & Pd & $\mathrm{Hg}$ & $\sum w t . \%$ & $\mathbf{N}_{\mathrm{Au}}$ & Formula & Minerals in Intergrowth \\
\hline p.1 & 81.41 & 11.92 & 2.32 & 0.70 & 0.79 & 97.43 & 866 & $\mathrm{Au}_{0.72} \mathrm{Ag}_{0.19} \mathrm{Cu}_{0.07} \mathrm{Pd}_{0.01} \mathrm{Hg}_{0.01}$ & $\mathrm{Qz} ; \mathrm{Ab} ; \mathrm{Kfs} ; \mathrm{AuCu} ; \mathrm{AuV}_{930}$; U-Mert \\
\hline p.1 & 82.42 & 12.02 & 2.46 & 0.82 & 0.96 & 98.9 & 865 & $\mathrm{Au}_{0.72} \mathrm{Ag}_{0.19} \mathrm{Cu}_{0.07} \mathrm{Pd}_{0.01} \mathrm{Hg}_{0.01}$ & $-"-$ \\
\hline p. 5 & 81.77 & 12.2 & 1.69 & 0.55 & 0.76 & 96.97 & 843 & $\mathrm{Au}_{0.74} \mathrm{Ag}_{0.2} \mathrm{Cu}_{0.04} \mathrm{Pd}_{0.01} \mathrm{Hg}_{0.01}$ & $\mathrm{Qz} ; \mathrm{Cr}-\mathrm{Ms} ; \mathrm{AuCu}$ \\
\hline p. 5 & 82.23 & 12.41 & 1.8 & 0.52 & 0.65 & 97.61 & 842 & $\mathrm{Au}_{0.73} \mathrm{Ag}_{0.2} \mathrm{Cu}_{0.05} \mathrm{Pd}_{0.01} \mathrm{Hg}_{0.01}$ & $-“-$ \\
\hline p.5 & 83.03 & 12.5 & 1.89 & 0.72 & 0.86 & 99.00 & 839 & $\mathrm{Au}_{0.73} \mathrm{Ag}_{0.2} \mathrm{Cu}_{0.05} \mathrm{Pd}_{0.01} \mathrm{Hg}_{0.01}$ & $-"$ - \\
\hline
\end{tabular}

Abbreviations of minerals: fuchsite (Cr-Ms), quartz (Qz), albite (Ab), K-feldspar (Kfs), tetra-auricupride (AuCu), U-mertieite (U-Mert).

\subsubsection{Native Gold of Fineness $930-1000 \%$}

High-fineness gold (930-1000\%) (type V) is present in all studied rhyolite samples in the form of microveinlets and microinclusions in native gold of types II-IV (see Section 4.2.1, Section 4.2.2 and Section 4.2.3) (Tables 2-4). It contains 5.6 wt.\% Ag and 2.8 wt.\% $\mathrm{Cu}$ and Pd (Table 6). High-fineness gold with one or two of these impurity elements or pure gold without any impurity also occur (Figure 6g,j, Figure 7f,h and Figure 9a). It is worth noting that $\mathrm{Hg}$ is absent in native gold of type $\mathrm{V}$.

Table 6. Representative analyses of high-fineness gold 930-1000\% (type V) and minerals in intergrowth with it in rhyolites from the Slavnaya ore zone (Nos. 2-4, Figures 6a, 7a and 9a) (EPMA data in wt.\% and formula).

\begin{tabular}{|c|c|c|c|c|c|c|c|c|}
\hline $\mathbf{N}$ & $\mathrm{Au}$ & Ag & $\mathrm{Cu}$ & $\mathbf{P d}$ & $\sum w t . \%$ & $\mathbf{N}_{\mathrm{Au}}$ & Formula & Minerals in Intergrowth \\
\hline \multicolumn{9}{|c|}{ No.2 } \\
\hline p.6 & 93.41 & 1.23 & 0.93 & 1.12 & 96.7 & 966 & $\mathrm{Au}_{0.93} \mathrm{Ag}_{0.02} \mathrm{Cu}_{0.03} \mathrm{Pd}_{0.02}$ & $\mathrm{AuII}_{860}$ \\
\hline p.6 & 89.02 & 2.14 & 1.76 & 1.28 & 94.2 & 945 & $\mathrm{Au}_{0.88} \mathrm{Ag}_{0.04} \mathrm{Cu}_{0.05} \mathrm{Pd}_{0.02}$ & $-"$ - \\
\hline p.6 & 87.08 & 2.18 & 2.27 & 1.95 & 93.49 & 932 & $\mathrm{Au}_{0.86} \mathrm{Ag}_{0.04} \mathrm{Cu}_{0.07} \mathrm{Pd}_{0}$ & $-"$ - \\
\hline p.7 & 99.15 & 0.46 & 0 & 0.94 & 100.55 & 986 & $\mathrm{Au}_{0.97} \mathrm{Ag}_{0.01} \mathrm{Pd}_{0.02}$ & $-"$ - \\
\hline \multicolumn{9}{|c|}{ No.3 } \\
\hline p.1a & 94 & 0.43 & 2.34 & 2.42 & 99.19 & 948 & $\mathrm{Au}_{0.88} \mathrm{Ag}_{0.01} \mathrm{Cu}_{0.07} \mathrm{Pd}_{0.04}$ & $\mathrm{AuIII}_{840}$ \\
\hline p.1a & 95.85 & 0 & 2.78 & 2.24 & 100.87 & 950 & $\mathrm{Au}_{0.88} \mathrm{Cu}_{0.08} \mathrm{Pd}_{0.04}$ & -“- \\
\hline p.1b & 97.03 & 0 & 1.85 & 1.08 & 99.97 & 971 & $\mathrm{Au}_{0.93} \mathrm{Cu}_{0.05} \mathrm{Pd}_{0.02}$ & $\mathrm{AuII}_{860}$ \\
\hline p.1b & 97.88 & 0 & 0 & 0 & 97.88 & 1000 & $\mathrm{Au}_{1.0}$ & $-"$ - \\
\hline p.1b & 99.04 & 1.65 & 0.23 & 0 & 100.91 & 981 & $\mathrm{Au}_{0.96} \mathrm{Ag}_{0.03} \mathrm{Cu}_{0.01}$ & $-"$ \\
\hline p.3a & 93.49 & 5.64 & 0.55 & 1.04 & 100.72 & 928 & $\mathrm{Au}_{0.86} \mathrm{Ag}_{0.1} \mathrm{Cu}_{0.02} \mathrm{Pd}_{0.02}$ & $\mathrm{AuIII}_{860}$ \\
\hline p. $4 b$ & 97.02 & 0 & 1.16 & 2.78 & 100.96 & 961 & $\mathrm{Au}_{0.92} \mathrm{Cu}_{0.05} \mathrm{Pd}_{0.03}$ & AuII840 \\
\hline \multicolumn{9}{|c|}{ No.4 } \\
\hline p.1 & 97.68 & 0 & 1.66 & 1.33 & 100.17 & 930 & $\mathrm{Au}_{0.95} \mathrm{Cu}_{0.03} \mathrm{Pd}_{0.02}$ & AuIV860 \\
\hline
\end{tabular}

Abbreviations of minerals: native gold (type II, III, IV) (AuII, AuIII, AuIV).

The specific features of high-fineness gold are its high porosity, which resulted in the reduced total contents of components during the analysis (Table 6), and recrystallization. These features were observed in sample No.2 (p.6) (Figure 6j), in which we detected porous gold of type $\mathrm{V}$ with the highest content of $\mathrm{Pd}(2.8 \mathrm{wt} . \%)$ and lower concentrations of $\mathrm{Ag}$ and $\mathrm{Cu}$ than in the matrix of native gold of types II-IV, which suggests the removal of $\mathrm{Ag}$ and $\mathrm{Cu}$ and supply of Pd (Table 6). High-fineness gold (930-1000\%) (type V) in the marginal parts of $\mathrm{Ag}, \mathrm{Cu}$-bearing gold (type II) (Figure 6j) comes into contact with albite and fuchsite. 


\subsubsection{Au-Cu Intermetallides}

$\mathrm{Au}-\mathrm{Cu}$ phases were detected in the form of individual microinclusions of idiomorphic shape and thin platelets in lattice decay structures of solid solutions in some large particles of native gold (types II-IV) in rhyolite samples No.2-4. The compositions of $\mathrm{Au}-\mathrm{Cu}$ intermetallides and matrix for two samples Nos.2, 3 are given in Table 7. These data show that $\mathrm{Au}-\mathrm{Cu}$ intermetallides are similar to $\mathrm{AuCu}$ phase with minor amounts of $\mathrm{Pd}$ or $\mathrm{Ag}$.

The $\mathrm{AuCu}$ phase intergrown with native gold of type II and an exsolution texture is absent (Figure 7e-h) in sample No.3 (Section 4.2.2). The size of inclusions is no more than $12 \mu \mathrm{m}$. The content of Pd is $0.6-1.1 \mathrm{wt} . \%$, which corresponds to the formula $\mathrm{Au}_{1.06-1.1} \mathrm{Cu}_{0.92-0.88} \mathrm{Pd}_{0.02}$.

The $\mathrm{AuCu}$ phase in the form of thin platelets $(1-2 \times 10-20 \mu \mathrm{m})$ in lattice decay structures is typical of native gold III in sample No.2 (Figure 6a, p.2) (Section 4.2.3) and native gold IV in sample No.4a (Figure 9a,f). The content of Pd in the thin platelets in sample No.2 (p.2) does not exceed 0.36 wt.\% (Table 3), that of Ag varies in a narrow range of $0.3-0.8 \mathrm{wt} . \%$, and the amount of $\mathrm{Au}$ is higher than the ideal composition of $\mathrm{AuCu}$ $\left(\mathrm{Au}_{1.04-1.06} \mathrm{Cu}_{0.92-0.94} \mathrm{Pd}_{0.02-0.01} \mathrm{Ag}_{0-0.01}\right)$.

Table 7. Representative analyses of AuCu phases and mineral matrix (EPMA data in wt.\% and formula).

\begin{tabular}{|c|c|c|c|c|c|c|c|c|}
\hline $\mathbf{N}$ & $\mathrm{Au}$ & Ag & $\mathrm{Cu}$ & $\mathbf{P d}$ & $\sum w t . \%$ & $\mathbf{N}_{\mathrm{Au}}$ & Formula & Minerals in Intergrowth \\
\hline \multicolumn{9}{|c|}{ No.3 } \\
\hline p.1a & 76.58 & 0 & 21.26 & 0.75 & 98.59 & 777 & $\mathrm{Au}_{1.06} \mathrm{Cu}_{0.92} \mathrm{Pd}_{0.02}$ & $\mathrm{AuIII}_{840}$ \\
\hline p.1a & 76.35 & 0 & 21.4 & 1.1 & 98.85 & 772 & $\mathrm{Au}_{1.06} \mathrm{Cu}_{0.92} \mathrm{Pd}_{0.02}$ & $-"$ - \\
\hline p.1b & 76.96 & 0 & 21.28 & 0.63 & 98.87 & 778 & $\mathrm{Au}_{1.07} \mathrm{Cu}_{0.91} \mathrm{Pd}_{0.02}$ & AuIII 860 \\
\hline p.1b & 77.04 & 0 & 21.29 & 0.73 & 99.06 & 778 & $\mathrm{Au}_{1.07} \mathrm{Cu}_{0.91} \mathrm{Pd}_{0.02}$ & $-"$ - \\
\hline p.1b & 77.01 & 0 & 19.80 & 0.62 & 97.43 & 790 & $\mathrm{Au}_{1.1} \mathrm{Cu}_{0.88} \mathrm{Pd}_{0.02}$ & $-“-$ \\
\hline \multicolumn{9}{|c|}{ No.2 } \\
\hline p. 2 & 77.20 & 0.29 & 22.37 & 0.36 & 100.23 & 770 & $\mathrm{Au}_{1.04} \mathrm{Cu}_{0.94} \mathrm{Pd}_{0.01} \mathrm{Ag}_{0.01}$ & $\mathrm{AuII}_{830-860}$ \\
\hline p. 2 & 77.12 & 0.84 & 21.52 & 0 & 99.48 & 775 & $\mathrm{Au}_{1.06} \mathrm{Cu}_{0.92} \mathrm{Ag}_{0.02}$ & $-"-$ \\
\hline
\end{tabular}

Abbreviations: native gold of types II and III (AuII, AuIII).

We failed to determine the composition of the $\mathrm{Au}-\mathrm{Cu}$ phases in native gold of type IV in sample No.4a (Figure 9a,f) owing to poor visualization on the optical and scanning microscopes and small thickness of the plates $(<1 \mu \mathrm{m})$.

\subsection{Reconnaissance of Fluid Inclusions}

A limited number of fluid inclusions were studied in albite and quartz in rhyolites from the Slavnaya and Ludnaya ore zones (Figure 10). While the data are too few data to draw firm conclusions, they are sufficient to allow us to hypothesize about the nature of the hydrothermal system. In rhyolite samples from the Slavnaya zone, albite and quartz are associated with native gold of types II-IV, which suggests their synchronous crystallization (Figures $6 c$,e and $7 \mathrm{a}-\mathrm{e}$ ). In rhyolite samples from the Ludnaya zone, albite and quartz do not contain gold particles, but are intergrown with fuchsite in which native gold of type I is localized (Figures 3 and 4 ).

Fluid inclusions are classified as primary inclusions when they occur along growth zones (Figure 10a,b) or are isolated (Figure 10c,d). Secondary inclusions in quartz form trails in cracks. The size of fluid inclusions is no more than 10-15 $\mu \mathrm{m}$. 

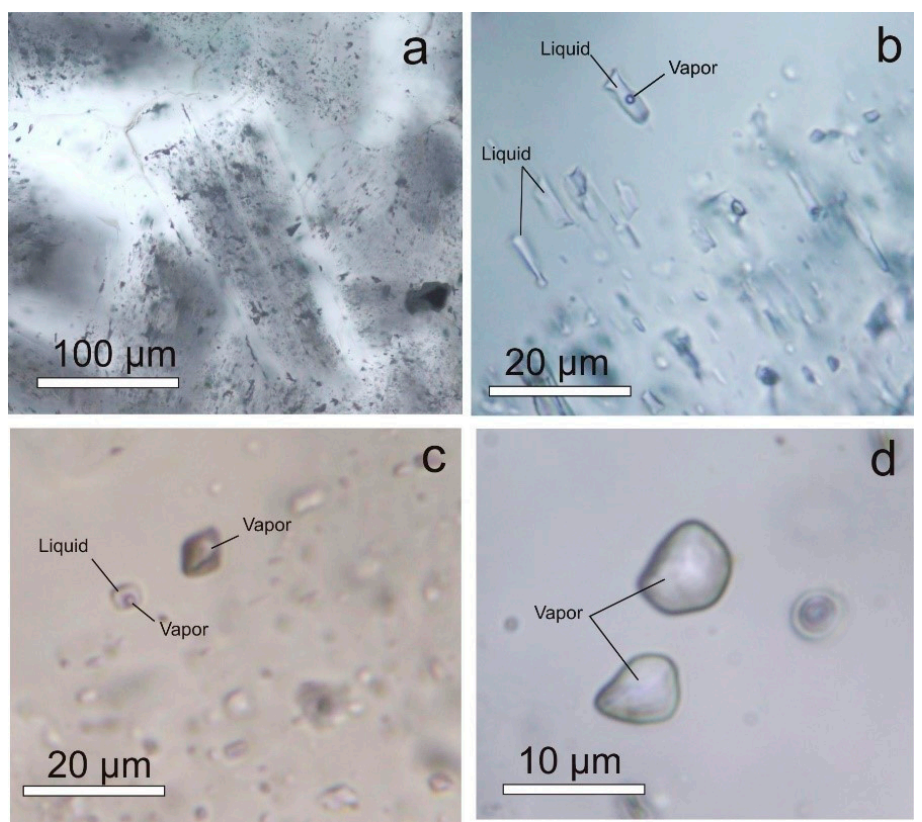

Figure 10. Albite crystals saturated with primary fluid inclusions (a); primary vapor-liquid twophase and liquid single-phase fluid inclusions tracing the growth zone in albite (b) (a,b) - Slavnaya ore zone); primary two-phase and vapor inclusions in quartz (c); primary vapor inclusions in quartz (d) (c,d)-Ludnaya ore zone).

\subsubsection{The Ludnaya Ore Zone}

Only 9 primary fluid inclusions were analyzed from the Ludnaya ore zone. In albite and quartz, two-phase inclusions are homogenized in the temperature range of 186 to $139^{\circ} \mathrm{C}$ (Table 8). Melting of eutectic takes place at $-39^{\circ} \mathrm{C}$. The temperature is close to the eutectic temperature of the $\mathrm{MgCl}_{2}-\mathrm{KCl}-\mathrm{H}_{2} \mathrm{O}$ system $\left(-37.8^{\circ} \mathrm{C}\right)$. Complete melting of ice in frozen inclusions in albite takes place at -0.3 to $0.1^{\circ} \mathrm{C}$. The salinity of solutions varies from 2.1 to $0.2 \mathrm{wt} . \% \mathrm{NaCl}$ eq.

Table 8. Results of primary two-phase fluid inclusion study by cryo- and thermometry.

\begin{tabular}{cccccc}
\hline Sample & Mineral & Th ${ }^{\circ} \mathbf{C}$ & Teu ${ }^{\circ} \mathbf{C}$ & Tice ${ }^{\circ} \mathbf{C}$ & Salinity (wt. $\%$ NaCl eq.) \\
\hline \multicolumn{7}{c}{ Rhyolite from Ludnaya ore zone } \\
\hline 3p-1154-2 (4) & albite & $155-139$ & -39 & -0.3 to -0.1 & $0.5-0.2$ \\
3p-1154-2 (5) & quartz & $186-178$ & -39 & -1.2 to -0.7 & $2.1-1.2$ \\
\hline \multicolumn{7}{c}{ Rhyolite from Slavnaya ore zone } \\
\hline 3p-1122-1 (10) ${ }^{*}$ & albite & $130-113$ & -39 to -38 & -15 to -7.5 & $18.6-11$ \\
3p-1122-1 (5) & quartz & $165-105$ & -55 & -10 to -7.5 & $13.9-11$ \\
3p-1122-13 (4) & albite & $133-125$ & -49 & -17 to -13 & $20.2-16.9$ \\
\hline
\end{tabular}

Note: ${ }^{*}$-number of fluid inclusions; Th—homogenization temperature, Teu—melting of eutectic and Ticemelting of ice.

\subsubsection{The Slavnaya Ore Zone}

Only 19 primary fluid inclusions were analyzed from the Slavnaya ore zone. In quartz and albite, two-phase fluid inclusions are homogenized in the temperature range from 165 to $105^{\circ} \mathrm{C}$. In these inclusions, melting of eutectic is observed at $-49^{\circ} \mathrm{C}$, which is similar to the melting temperatures of eutectic of the $\mathrm{CaCl}_{2}-\mathrm{KCl}-\mathrm{H}_{2} \mathrm{O}\left(-50.5^{\circ} \mathrm{C}\right)$ and $\mathrm{CaCl}_{2}-\mathrm{H}_{2} \mathrm{O}$ $\left(-49.8^{\circ} \mathrm{C}\right)$ systems. Ice melts at temperatures from -15 to $-7.5^{\circ} \mathrm{C}$. The salinity of solutions of fluid inclusions varies from 20.2 to $11 \mathrm{wt} . \% \mathrm{NaCl}$ eq. (Table 8). 


\section{Discussion}

The mechanism of formation of native gold of varying chemical composition is very complicated and depends on many factors [22-28]. The content of elements in native gold is determined by their concentrations in hydrothermal solutions, which are governed by temperature, redox conditions, $\mathrm{pH}$, presence of ligand elements $\mathrm{Cl}, \mathrm{S}$, and elements such as $\mathrm{Se}, \mathrm{Te}, \mathrm{As}, \mathrm{Sb}$. A wide spectrum of impurity elements in native gold is related to different geochemical conditions in which mobilization, transportation, and deposition of gold-ore mineralization took place. Nowadays, several hypotheses on the role and ratios of magmatic, metamorphic, and hydrothermal processes during the formation of $\mathrm{Au}-\mathrm{Pd}$ mineralization are discussed. Fluids are considered to play an important role in the genesis of mafic-ultramafic complexes with mineralization of noble metals [29-36]. The efficiency of mobilization, transportation, and deposition of noble metals with participation of fluids at the magmatic and post-magmatic stages of evolution of the ore-forming process is shown in the experiments [37]. The precipitation of these metals from hydrothermal solutions is the main process of concentrating of metals and they can form their own mineral phases or occur as an isomorphic impurity in other minerals. The fineness and set of impurity elements in native gold, and associated minerals are the indicators of different genetic origin [28,38-43].

Pd-bearing native gold occurs both in magmatic sulfide ores and in low-sulfide post-magmatic metasomatites [44,45]. Large occurrences of low-sulfide, essentially AuPd mineralization in different types of mafic-ultramafic complexes are known in the Norilsk district (Talnakhskoye, Norilsk-1 and 2, Chernogorskoe, Vologochanskoe), in the Skaergaard formation, in John Melville reef of the Stillwater complex and some others [46]. The elevated $\mathrm{Cu}$ content in native gold indicates the probable genetic relation of gold mineralization with mafic-ultramafic complexes or with the deposits of copper type (copperskarn, copper-pyrite and porphyry copper) [47-50].

\subsection{Compositions of Native Gold and Minerals in Intergrowth}

The study reveals differences in the set and quantity of impurity elements in the composition of native gold, intergrown minerals, and PTX parameters of the deposition of Au-Pd mineralization in two ore zones of the Chudnoe deposit. The obtained results (Figure 11a) together with the earlier published data (Figure 11b) allowed us to distinguish five types of native gold. Both the data from previous works $[2,3,5]$ and our results (Table 2) show that native gold (type I) from the Ludnaya ore zone contains only Ag. The fineness of native gold varies within the range of 510 to $790 \%$. Native gold in this ore zone occurs in the form of impregnated particles commonly intergrown with arsenoantimonide in a fuchsite or allanite matrix (Figures 2-5). Palladium arsenoantimonide intergrown with native gold (type I) is represented by U- or Cu-mertieite-II. In this type of native gold, we did not detect $\mathrm{Pd}, \mathrm{Cu}$, and $\mathrm{Hg}$ impurities even under long-term accumulation of spectra (see Section 3).

In rhyolites of the Slavnaya ore zone, native gold is heterogeneous, has a higher fineness, different sets and amounts of impurities: II type-Au-Ag-Cu solid solution (840-860\%); III-Au-Ag-Cu-Pd (830-890\%), IV-Au-Ag-Pd-Cu-Hg (840-870\%), as well as a specific mineral composition of the surrounding matrix-fuchsite or allanite, albite, and mertieite-II (II); albite, quartz, and atheneite (III); quartz, albite, K-feldspar, and mertieite-II (IV) (Tables 3-5, Figures 3-9). It is worth noting that native gold of II and IV types shows some similarity with native gold of type I, as it occurs in paragenesis with fuchsite or allanite (II type) and mertieite-II (types II and IV). 

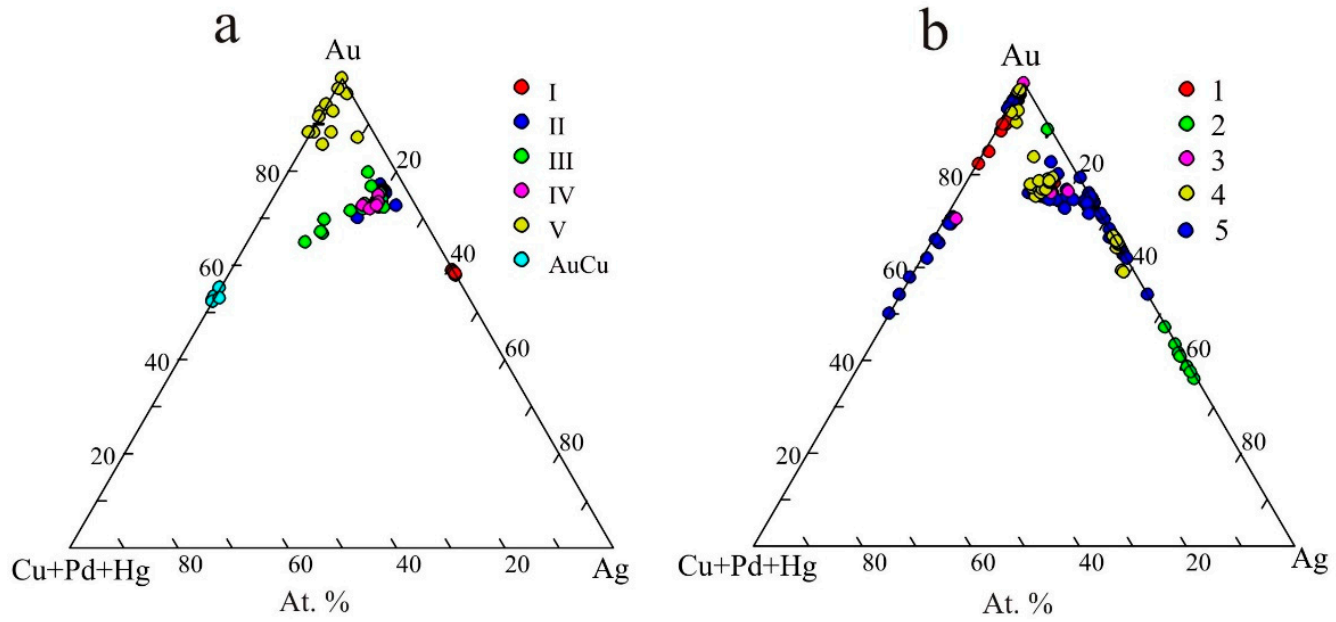

Figure 11. Chemical composition of various types of native gold from the Chudnoe deposit on the ternary diagram $\mathrm{Au}-\mathrm{Ag}-\mathrm{Cu}(+\mathrm{Pd}+\mathrm{Hg})$ from the results of present study (a) and data of other authors (b): 1-[1]; 2-[2];3-[5]; 4-[3]; $5[7,14-16]$.

In this study we revealed lattice decay structures with tetra-auricupride $\mathrm{AuCu}$ for native gold of types III $(\mathrm{Ag}, \mathrm{Cu}, \mathrm{Pd})$ and IV $(\mathrm{Ag}, \mathrm{Cu}, \mathrm{Pd}, \mathrm{Hg})$. $\mathrm{AuCu}$ intermetallide is present in native gold of type II but in the form of isometric microinclusions. Intermetallides of $\mathrm{AuCu}$, $\mathrm{Au}_{3} \mathrm{Cu}, \mathrm{Au}_{3} \mathrm{Cu}_{2}, \mathrm{Au}_{2} \mathrm{Cu}, \mathrm{AuCu}_{3}$ composition were reported by other authors $[5,8,16,50,51]$.

The phase diagram $\mathrm{Au}-\mathrm{Cu}$ [52] shows that the presence of lattice decay structures with thin platelets of tetra-aucupride $\mathrm{AuCu}$ in native gold indicates temperatures $410{ }^{\circ} \mathrm{C}$. $\mathrm{Au}-\mathrm{Cu}$ intermetallides of composition $\mathrm{Au}_{3} \mathrm{Cu}$ and $\mathrm{AuCu}_{3}$ are formed at temperatures below 390 and $240{ }^{\circ} \mathrm{C}$. The formation of decay structures in the initially homogeneous solid solution results from the decrease in the miscibility of components and their redistribution with decreasing in temperature. Such structures were also found at other objects: Zolotaya Gora, Melent'evskoe deposits (Southern Urals, Russia) [53,54], Agardag ultramafic massif (S. Tuva, Russia) [44], the 15 Mile deposit (the Dease Lake district, British Columbia) [55], Au-Pd ores of the Skaergaard massif (Greenland) [45].

\subsection{Inferences on the PTX Parameters of Au-Pd-REE Mineralization}

Data on the PTX parameters of formation of Au-Pd-REE mineralization at the Chudnoe deposit were for the first time obtained by Surenkov et al. [12,56]. They used thermocryometry to analyze 110 vapor-liquid inclusions of which the vapor-liquid inclusions in albite and pre-ore quartz were attributed to primary inclusions. In early veined quartz, homogenization temperature ranged from 230 to $400{ }^{\circ} \mathrm{C}$, and salt concentrations, from 2.1 to $17 \mathrm{wt} . \% \mathrm{NaCl}$ eq. For late generations of quartz, albite and calcite, which reflect the conditions for the formation of Au-Pd mineralization, temperature ranged from 100 to $180^{\circ} \mathrm{C}$ and the concentrations of salts, from 2.5 to $23 \mathrm{wt} . \% \mathrm{NaCl}$ eq. Surenkov [12] suggests that at the early stage, the Chudnoe deposit was formed with participation of metamorphic fluids and the formation of $\mathrm{Au}-\mathrm{Pd}$ mineralization took place at lower temperatures with participation of meteoric, marine, or buried waters.

Our limited study of fluid inclusions are generally consistent with the data of Surenkov et al. [12,56]. Ore-forming fluids of Ludnaya and Slavnaya ore zones range salinity from 2.1 to 0.2 and from 20.2 to $11 \mathrm{wt} . \% \mathrm{NaCl}$ eq., respectively. It is known, however, that mineral parageneses with quartz, albite and sericite (fuchsite) in gold deposits are formed at the temperatures higher than $200-230{ }^{\circ} \mathrm{C}$ [57]. At lower temperatures, argillisites form, in which sericite is commonly replaced by mixed-layer minerals of clay series. These data allow us to estimate the possible pressure of ore formation by comparing the formation temperature of the quartz-albite-sericite (fuchsite) mineral association in gold deposits with isochores of fluid inclusions solutions. 
Gold mineralization at the Ludnaya ore zone was formed synchronously with the quartz-albite-fuchsite association. Thus, the trapping pressure of fluid inclusions could vary from 23 to $114 \mathrm{MPa}$ at temperatures from 200 to $230{ }^{\circ} \mathrm{C}$ (Figure 12) in this zone. Gold mineralization at the Slavnaya ore zone was formed later than the quartz-albite-fuchsite association at $105-165^{\circ} \mathrm{C}$, the trapping pressure of fluid inclusions could vary from 5 to $115 \mathrm{MPa}$ (Figure 12).

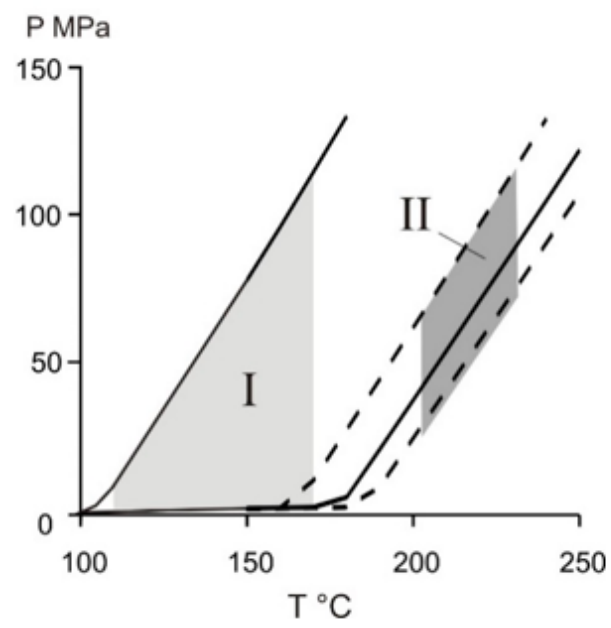

Figure 12. Isochores of fluids from the Slavnaya zone (solid line) and fluids from the Ludnaya zone (dashed line). Isochores were constructed using the "AqSo-NaCl: computer program" for extreme temperatures and homogenization concentrations [21]. The probable trapping PT conditions of fluid inclusions are highlighted in light gray for the Slavnaya zone (I) and in dark gray for Ludnaya zone (II).

Thus, it can be assumed that the PT parameters of formation of Au-Pd mineralization associated with fuchsite, especially in early rhyolites from the Slavnaya zone, are suggested to be higher than those estimated in the fluid inclusion study. The fluids forming Au-Pd mineralization at the Chudnoe deposit are similar in salt composition to the ore-forming fluids of hydrothermal Au-Ag deposits, though the latter are characterized by higher formation temperatures, higher salinity of fluids and frequent presence of dense gases $\left(\mathrm{CO}_{2}, \mathrm{~N}_{2}, \mathrm{CH}_{4}\right)$ in the composition of fluids [58]. They are similar in temperature, concentration, and composition of salts (Ca-Na-K chlorides, carbonates, and hydrocarbonates) to the ore-forming fluids of Au-Pd deposits (Serra Pelada, Bleida Far West), for which an infiltration model of formation with participation of oxidized basin Na-Ca chloride waters is assumed [59-61]. However, these deposits are characterized by the presence of Se-bearing PGM (Pd-Pt-Se, Pd-Se, Pd-Hg-Se, and Pd-Bi-Se phases, and sudovikovite and palladseite) [62].

Seven metals (Ag, Cu, Pd, Hg, Sn, Tl, Fe), three chalcogenes (Te, S, Se) and three metalloids (As, $\mathrm{Sb}, \mathrm{Bi}$ ) can be indicators of the presence of gold minerals in ores [63]. Four of these metals- $\mathrm{Ag}, \mathrm{Cu}, \mathrm{Pd}$, and $\mathrm{Hg}$-were detected in the composition of native gold from the Slavnaya ore zone (Chudnoe deposit). $\mathrm{Cu}$ also formed intermetallides with $\mathrm{Au}$. As, Sb, and $\mathrm{Hg}$, found in elevated concentrations in the Chudnoe ores, under specific conditions of ore formation were deposited as Pd minerals with these elements-arsenides (atheneite), arsenoantimonides (mertieite-I, mertieite-II, isomertieite), antimonides (stibiopalladinite) [1-3,8].

Zaccarini et al. [64] think that the Pd content in native gold is determined by the evolution of $\mathrm{S}, \mathrm{Te}, \mathrm{As}, \mathrm{Sb}, \mathrm{Bi}$, Se concentrations in a fluid, which bind palladium into its own minerals. Many authors $[4,64,65]$ suppose that with a decrease in temperature and change in redox conditions to more oxidizing, the concentrations of sulfide sulfur decrease and those of the palladium binding elements increase. Yanakieva and Spiridonov [36,66] reported that $\mathrm{Ag}-\mathrm{Au}-\mathrm{Pd}$ minerals are typical of telethermal gold deposits formed at low 
$f \mathrm{~S}_{2}$ and elevated $f \mathrm{O}_{2}$. They are regarded as the result of deposition of ore components from chloride hydrotherms that have a high oxidation potential. As selenides, tellurides, and bismuthides are not typical of the Chudnoe deposit, the composition of native gold is likely determined by the evolution of $\mathrm{Au}, \mathrm{Ag}, \mathrm{Cu}, \mathrm{Pd}, \mathrm{Hg}, \mathrm{As}, \mathrm{Sb}$ concentrations in a fluid, which bind palladium into its own minerals-sulfoantimonides, atheneite, etc.

The data of Borisov from [5] show that the formation of Au-Pd-REE mineralization of ore occurrences is the latest hydrothermal event related to the regressive stage of the Late Hercynian metamorphism. The formation of Au-Pd-REE mineralization of the Chudnoe deposit resulted from the oxidation of ascending reduced metamorphic solutions, which was also accompanied by an increase in their acidity. The part of the oxidation geochemical parameter was played by hematite-rich rocks in the zone of regional unconformity. The conditions of ore deposition at the Chudnoe deposit, according to this author, correspond to $\log f \mathrm{O}_{2} \sim-47, \mathrm{pH} \sim 4.5$ at $150{ }^{\circ} \mathrm{C}$. Changes in the set of minerals and their composition are due to the vertical variability of redox conditions and acidity of solutions, which in turn are a result of the different localizations of objects relative to the regional unconformity.

\subsection{Genesis of Au-Pd Mineralization, Sources of Ore Components}

The genesis of the Chudnoe deposit is still debatable. There are several viewpoints on the origin of complex mineralization of this uncommon type. Tarbaev and coauthors [1] adhered to the hydrothermal genesis of Au-Pd-REE ores at the Chudnoe deposit, while $\mathrm{Cr}, \mathrm{Pd}, \mathrm{Au}$, and $\mathrm{Cu}$ were mobilized from presumably deep-seated mafic and ultramafic rocks, probably, andesite-basalts from the lower series of the Upper Riphean Sablegorskaya formation, and $\mathrm{K}$ and lanthanides, from the host porphyry rhyolites. Some researchers of the Chudnoe deposit $[5,12,13]$ suggest a metamorphic-hydrothermal model of formation: ascending metamorphic hydrothermal solutions mobilized metals from underlying rocks and the main factors of ore formation are oxidation and increase in the acidity of orebearing solutions. Originally, metamorphic solutions were reduced (field of stability of pyrite and magnetite), weakly-acidic - near-neutral (acidity was controlled by the quartzK-feldspar-muscovite association). At the later stages of the process, during the formation of Au-Pd mineralization, considerable amounts of meteoric and buried waters participated in the hydrothermal system [12].

On the basis of the results of isotopic and mineralogical study, Galankina [2] shows that Au-Pd-REE mineralization of the Chudnoe deposit should be regarded as hydrothermal, originated in the Riphean after the formation of Sablegor and Maldin rhyolites, occurring in the zone of the deep Maldinskiy fault and represented by pre-ore metasomatites which are the most similar to the berezite-listvenite formation and ore-accompanying near-crack quartz-albite metasomatites and listvenite-like rocks. There are reasons to assume that $\mathrm{Cr}$ and $\mathrm{Pd}$ mineralization of the Chudnoe deposit is related to the fact that hydrothermal processing of riftogenic complexes localized in the Maldinskiy fault involved ultramafic rocks that are not exposed on the surface. Such complexes of the Riphean age widely occur within the Central-Ural uplift, e.g., Saranovskii massif. Magnetic survey data show the occurrence of a positive magnetic anomaly at the depth, which suggests that the intrusion chamber could be the source of the ore-forming fluid [67].

Co-occurrence of native gold and fuchsite was observed at many gold deposits [68-70]. The associations of fuchsite with native gold can be found in altered ultramafic rocks at Kalgoorlie (Australia), the Kerr-Addison and Dome mines, in the Virginiatown and Porcupine mining districts of northeast Ontario, Canada; the Mother Lode district in California, USA; in the Transvaal district of South Africa (including, confusingly, the Murchison Range); British Columbia and the Yukon, Quebec and Newfoundland; Ireland; Morocco; Egypt; and Saudi Arabia [68]. However, these deposits are characterized by a listvenite or QAM (quartz-ankerite-mariposite) type of hydrothermal alteration formed by the mafic-ultramafic host rocks.

Native gold in listvenites is also typical of many Ural objects [71]. Mechnikovskoe, Altyn-Tash, and Ganeevskoe belong to the listvenite-related gold deposits, which occur 
in the large Main Uralian fault zone and some smaller faults within the Magnitogorsk zone (South Urals). Listvenites are developed after serpentinites and composed of quartz, fuchsite (or mariposite), and carbonates (magnesite, dolomite) \pm albite. Volcanic and volcanoclastic rocks are altered to beresites, consisting of sericite, carbonates (dolomite, ankerite), quartz, and albite. The process of alteration occurs under the influence of $\mathrm{CO}_{2}$ and S-rich fluids [72-74]. At the Chudnoe deposit under study, native gold is associated with fuchsite, but in the absence of carbonates and sulfides, which makes it different from other objects with listvenite or QAM (quartz-ankerite-mariposite) type of hydrothermal alteration and suggests the participation of $\mathrm{CO}_{2}$-free or low- $-\mathrm{CO}_{2}$ fluid.

The formation of native gold I (only with Ag impurity) in rhyolites of the Ludnaya ore zone is, most likely related to the processes of fuchsitization and allanitization of rhyolites with the supply of $\mathrm{Cr}$ and REE. The formation of native gold with $\mathrm{Ag}, \mathrm{Cu}, \mathrm{Pd}$, and $\mathrm{Hg}$ impurities (types II-IV), supposedly, took place during the following metasomatic processes: silicification, albitization, and feldspathization in rhyolites. The intersections of quartz-albite metasomatites with fuchsite veinlets support such an assumption. The porous texture of high-fineness gold (type $\mathrm{V}$ ) is explained by the removal of $\mathrm{Cu}$ and $\mathrm{Ag}$. The association of native gold with palladium minerals and presence of $\mathrm{Cu}$ and $\mathrm{Pd}$ in it, $\mathrm{Cr}$ in fuchsite indicate the relationship between ore formation and mafic-ultramafic magmatism.

Author Contributions: Conceptualization, methodology, G.P. and V.M.; investigation, G.P., N.K., and A.B.; writing and editing, G.P., V.M., N.K. and A.B.; visualization G.P., V.M., S.K. and A.B.; supervision G.P. All authors have read and agreed to the published version of the manuscript.

Funding: This research was funded with financial support from the Russian Foundation of Basic Research (project No 20-05-00393) and by within the framework of the state assignment of Sobolev Institute of Geology and Mineralogy, Zavaritsky Institute of Geology and Geochemistry (AAAA-A18118052590028-9), Institute of Geology, Komi Science Center (Russian Academy of Sciences).

Acknowledgments: We are very grateful to the Reviewers and Academic Editors for their helpful comments that improved our manuscript.

Conflicts of Interest: The authors declare no conflict of interest.

\section{References}

1. Tarbaev, M.B.; Kuznetsov, S.K.; Moralev, G.V.; Soboleva, A.A.; Laputina, I.P. New gold-palladium type of mineralization in the Kozhim Region of Circumpolar Ural (Russia). Geol. Ore Depos. 1996, 38, 11-25.

2. Galankina, O.L.; Gavrilenko, V.V.; Gaydamako, I.M. New data on mineralogy of hydrothermal gold-platinoid mineralization of the Subpolar Urals. Zapiski RMO 1998, 3, 72-78. (In Russian with English abstract)

3. Shumilov, I.K.; Ostashchenko, B.A. Mineralogical and Technological Peculiarities of Au-Pd-TR Metallization in the Subpolar Urals; Geoprint: Syktyvkar, Russia, 2000; p. 104.

4. Anikina, E.V.; Alekseev, A.V. Mineral-geochemical characteristic of gold-palladium mineralization in the Volkov gabbro massif (Platiniferous Urals Belt). Litosfera 2010, 5, 75-100. (In Russian with English abstract)

5. Borisov, A.V. Geological and Genetic Features of Au-Pd-REE Ore Occurrences in the Maldy-Nyrd Ridge (Subpolar Urals). Ph.D. Thesis, IGEM RAS, Moscow, Russia, 2005; p. 27. (In Russian)

6. Nikulova, N.Y.; Filippov, V.N. Native palladium in gold from conglomerates of the Telpos (O1TP) Formation Muldynyrd Ridge, Subpolar Urals. J. Proc. Komi Sci. Centre Ural Branch RAS 2009, 138, 69. (In Russian with English abstract)

7. Onishchenko, S.A.; Kuznetsov, S.K. Palladium-gold sulfide mineralization in andesites at the Chudnoe deposit (Subpolar Urals). J. Proc. Komi Sci. Centre Ural Branch RAS 2019, 294, 20-27. (In Russian with English abstract)

8. Kuznetsov, S.K.; Mayorova, T.P.; Shaibekov, R.I.; Sokerina, N.V.; Filippov, V.N. Mineral composition and conditions of formation of gold-platinum-palladium occurrences in the north of the Urals and Pai-Khoi. Geol. Miner. Resour. 2014, 3, 81-85. (In Russian with English abstract)

9. Pystin, A.M.; Potapov, I.L.; Pystina, Y.I.; Generalov, V.I.; Onishchenko, S.A.; Filippov, V.N.; Shloma, A.A.; Tereshko, V.V. Low-Sulfide Platinum-Metal Mineralization in the Polar Urals; Pystin, A.M., Ed.; Institute of Economics Ural Branch of RAS: Yekaterinburg, Russia, 2011; p. 150. (In Russian with English abstract)

10. Ozerov, V.S. Metamorfogennye rossypi zolota Pripolyarnogo Urala (Metamorphogenic gold placers in the Subpolar Urals). Ores Metals 1996, 4, 28-37. (In Russian)

11. Galankina, O.L. Peculiarities of Mineralogy of Palladium-Gold Occurrences of the Subpolar Urals. Ph.D. Thesis, St. PMU, Saint Petersburg, Russia, 2001; p. 156. (In Russian) 
12. Surenkov, S.V. Formation Conditions and Sources of Ore Matter Au-PGE-REE of Ore Occurrences in Alkesvozhskaya Area (Subpolar Urals). Ph.D. Thesis, IGEM RAS, Moscow, Russia, 2003; p. 23. (In Russian)

13. Moralev, G.V.; Borisov, A.V.; Surenkov, S.V.; Tarbaev, M.B.; Ponomarchuk, V.A. First 39Ar-40Ar datings on micas from the Chudnoe Au-Pd-REE occurrence, Near-Polar Urals. Dokl. Earth Sci. 2005, 400, 109-112.

14. Kuznetsov, S.K.; Onishchenko, S.A. Gold content of local areas of metasomatic alteration of rhyolites of the Chudnoe deposit (Subpolar Urals). J. Proc. Komi Sci. Centre Ural Branch RAS 2018, 288, 39-45. (In Russian with English abstract)

15. Kuznetsov, S.; Mayorova, T.; Sokerina, N.; Glukhov, Y. Gold-bearing areas of the western slope of Northern Urals and Timan. J. Proc. Komi Sci. Centre Ural Branch RAS 2018, 4, 81-94. [CrossRef]

16. Onishchenko, S.A.; Kuznetsov, S.K.; Tropnikov, E.M. Epigenetic alteration of cupreous gold in the Au-Ag-Cu-Pd exsolution texture. Dokl. Earth Sci. 2020, 492, 418-421. [CrossRef]

17. Lafuente, B.; Downs, R.T.; Yang, H.; Stone, N. The power of databases: The RRUFF project. In Highlights in Mineralogical Crystallography; Armbruster, T., Danisi, R.M., Eds.; De Gruyter: Berlin, Germany, 2015; pp. 1-30.

18. Chernova, A.E.; Moralev, G.V.; Tarbaev, M.B.; Kuznetsov, S.K.; Wolfson, A.A. Distribution and forms of occurrence of mercury in the Au-Pd-REE ore occurrence Chudnoye, Kozhimsky region, Subpolar Urals. In The Main Problems of Teaching About Magmatoid Ore Deposits; IGEM RAS: Moscow, Russia, 1997; pp. 172-173. (In Russian)

19. Borisenko, A.S. Cryometric analysis of salt composition of solutions of gas-liquid inclusions in minerals. In Application of Therobarogeochemical Methods in Prospecting and Study of Ore Deposits; Nedra: Moscow, Russia, 1982; pp. 37-47. (In Russian)

20. Bodnar, R.J.; Vityk, M.O. Interpretation of microthermometric data for $\mathrm{NaCl}-\mathrm{H}_{2} \mathrm{O}$ fluid inclusions, Fluid Inclusions in Minerals. In Methods and Applications; De Vivo, B., Frezzotti, M.L., Eds.; Virginia Polytechnic Institute State University: Blacksburg, VA, USA, 1994; pp. 117-131.

21. Bakker, R.J. AqSo NaCl: Computer program to calculate p-T-V-x properties in the $\mathrm{H}_{2} \mathrm{O}-\mathrm{NaCl}$ fluid system applied to fluid inclusion research and pore fluid calculation. Comput. Geosci. 2018, 115, 122-133. [CrossRef]

22. Fisher, N.H. The fineness of gold, with special reference to the Morobe gold field, New Guinea. Econ. Geol. 1945, 40, 449-495. [CrossRef]

23. Morrison, G.W.; Rose, W.J.; Jaireth, S. Geological and geochemical controls on the silver content (fineness) of gold in gold-silver deposits. Ore Geol. Rev. 1991, 6, 333-364. [CrossRef]

24. Gammons, C.H.; Williams-Jones, A.E. Hydrothermal geochemistry of electrum; thermodynamic constraints. Econ. Geol. 1995, 90, 420-432. [CrossRef]

25. Pal'yanova, G. Physicochemical modeling of the coupled behavior of gold and silver in hydrothermal processes: Gold fineness, $\mathrm{Au} / \mathrm{Ag}$ ratios and their possible implications. Chem. Geol. 2008, 255, 399-413. [CrossRef]

26. Liang, Y.; Hoshino, K. Thermodynamic calculations of $\mathrm{Au}_{\mathrm{x}} \mathrm{Ag}_{1-\mathrm{x}}$-Fluid equilibria and their applications for ore-forming conditions. Appl. Geochem. 2015, 52, 109-117. [CrossRef]

27. Palyanova, G.; Zinina, V.; Kokh, K.; Seryotkin, Y.; Zhuravkova, T.; Mikhlin, Y. New gold chalcogenides in the Au-Te-Se-S System. J. Phys. Chem. Solids 2020, 138, 109276. [CrossRef]

28. Chapman, R.J.; Banks, D.A.; Styles, M.T.; Walshaw, R.D.; Piazolo, S.; Morgan, D.J.; Grimshaw, M.R.; Spence-Jones, C.P.; Matthews, T.J.; Borovinskaya, O. Chemical and physical heterogeneity within native gold: Implications for the design of gold particle studies. Miner. Deposita 2021, 1-26. [CrossRef]

29. Letnikov, F.A. Fluid regime of endogenous processes and problems of ore genesis. Rus. Geol. Geophys. 2001, $47,1296$.

30. Williams-Jones, A.E.; Bowell, R.J.; Migdisov, A.A. Gold in Solution. Elements 2009, 5, 281-287. [CrossRef]

31. Murzin, V.V.; Sazonov, V.N. Origin of cupriferous gold mineralization in Alpine-type ultramafic rocks. Dokl. Earth Sci. 1999, 367, 634-635.

32. Duuring, P.; Hagemann, S.G.; Cassidy, K.F.; Johnson, C.A. Hydrothermal Alteration, Ore Fluid Characteristics, and Gold Depositional Processes along a Trondhjemite-Komatiite Contact at Tarmoola, Western Australia. Econ. Geol. 2004, 99, $423-451$. [CrossRef]

33. Rauchenstein-Martinek, K.; Wagner, T.; Walle, M.; Heinrich, C.A. Gold concentrations in metamorphic fuids: A LA-ICPMS study. Chem. Geol. 2014, 385, 70-83. [CrossRef]

34. Prokof'ev, V.Y. Main Principles of Hydrothermal Deposit Typification Based on Fluid Inclusion Study: The Case of Gold. Trans. Rus. Acad. Sci. Earth Sci. Sect. 2003, 354, 2553-2555. (In Russian)

35. Mountain, B.W.; Wood, S.A. Chemical controls on the solubility, transport and deposition of platinum and palladium in hydrothermal solutions: A thermodynamic approach. Econ. Geol. 1988, 83, 492-510. [CrossRef]

36. Spiridonov, E. Ore-magmatic systems of the Noril'sk ore field. Russ. Geol. Geophys. 2010, 51, 1059-1077. [CrossRef]

37. Gorbachev, N.S.; Dadze, T.P.; Kashirtseva, G.A.; Kunts, A.F. Fluid transfer of gold, palladium, and rare earth elements and genesis of ore occurrences in the Subpolar Urals. Geol. Ore Deposits 2010, 52, 215-233. [CrossRef]

38. Olivo, R.; Gauthier, M.; Bardoux, M. Palladian gold from the Caue iron mine, Itabira District, Minas Gerais, Brazil. Mineral. Mag. 1994, 58, 579-587. [CrossRef]

39. Varajão, C.; Colin, F.; Vieillard, P.; Melfi, A.; Nahon, D. Early weathering of palladium gold under lateritic conditions, Maquiné Mine, Minas Gerais, Brazil. Appl. Geochem. 2000, 15, 245-263. [CrossRef]

40. Cabral, A.R.; Lehmann, B.; Kwitko, R.; Jones, R.D. Palladian gold and palladium arsenide-antimonide minerals from Gongo Soco iron ore mine, Quadrilátero Ferrífero, Minas Gerais, Brazil. Appl. Earth Sci. 2002, 111, 74-80. [CrossRef] 
41. Chapman, R.J.; Leake, R.C.; Bond, D.P.G.; Stedra, V.; Fairgrieve, B. Chemical and Mineralogical Signatures of Gold Formed in Oxidizing Chloride Hydrothermal Systems and their Significance within Populations of Placer Gold Grains Collected during Reconnaissance. Econ. Geol. 2009, 104, 563-585. [CrossRef]

42. Chudnenko, K.V.; Palyanova, G.A.; Anisimova, G.S.; Moskvitin, S.G. Ag-Au-Hg solid solutions and physicochemical models of their formation in nature (Kyuchyus deposit as an example). Appl. Geochem. 2015, 55, 138-151. [CrossRef]

43. Palyanova, G.; Murzin, V.; Zhuravkova, T.; Varlamov, D. Au-Cu-Ag mineralization in rodingites and nephritoids of the Agardag ultramafic massif (southern Tuva, Russia). Russ. Geol. Geophys. 2018, 59, 238-256. [CrossRef]

44. Nielsen, T.F.D.; Andersen, J.C.O.; Holness, M.; Keiding, J.K.; Rudashevsky, N.S.; Rudashevsky, V.N.; Salmonsen, L.P.; Tegner, C.; Veksler, I.V. The Skaergaard PGE and Gold Deposit: The Result ofin situFractionation, Sulphide Saturation and Magma Chamber-scale Precious Metal Redistribution by Immiscible Ferich Melt. J. Pet. 2015, 56, 1643-1676. [CrossRef]

45. Rudashevsky, N.S.; Rudashevsky, V.N.; Nielsen, T.F.D.; Shebanov, A.D. Alloys and intermetallic compounds of gold and copper in gold-palladium ores of the Skaergard massif (Greenland). J. Proc. Komi Sci. Centre Ural Branch RAS 2014, $143,1-23$.

46. Sluzhenikin, S.F.; Mokhov, A.V. Gold and silver in PGE-Cu-Ni and PGE ores of the Noril'sk deposits, Russia. Miner. Depos. 2014, 50, 465-492. [CrossRef]

47. Palacios, C.; Hérail, G.; Townley, B.; Maksaev, V.; Sepulveda, F.; De Parseval, P.; Rivas, P.; Lahsen, A.; Parada, M.A. The composition of gold in the cerro casale gold-rich porphyry deposit, maricunga belt, Northern Chile. Can. Miner. 2001, 39, 907-915. [CrossRef]

48. Arif, J.; Baker, T. Gold paragenesis and chemistry at Batu Hijau, Indoneisa: Implications for gold-rich porphyry copper deposits. Miner. Depos. 2004, 39, 523-535. [CrossRef]

49. Chudnenko, K.; Pal'yanova, G. Thermodynamic properties of solid solutions in the Ag-Au-Cu system. Russ. Geol. Geophys. 2014, 55, 349-360. [CrossRef]

50. Gas'kov, I.V. Major impurity elements in native gold and their association with gold mineralization settings in deposits of Asian fold belts. Russ. Geol. Geophys. 2017, 58, 1080-1092. [CrossRef]

51. Murzin, V.V.; Sustavov, S.G. Solid-phase transformation in natural cuprous gold. Izv. USSR Acad. Sci. Ser. Geol. 1989, 11, 94-104. (In Russian)

52. Okamoto, H.; Charkrabarti, D.J.; Laugylin, D.E.; Massalski, T.B. The Au-Cu (Gold-Copper) System. Bull. Alloy Ph. Diagr. 1987, 8, 454-473. [CrossRef]

53. Spiridonov, E.M.; Pletnev, P.A. Zolotaya Gora Cupriferous Gold Deposit “Gold-Rodingite" Formation; Spiridonov, E.M., Ed.; Nauchnyi Mir: Moscow, Russia, 2002; p. 220. (In Russian)

54. Murzin, V.V.; Chudnenko, K.V.; Palyanova, G.A.; Varlamov, D.A.; Naumov, E.A.; Pirajno, F. Physicochemical model of formation of $\mathrm{Cu}-\mathrm{Ag}-\mathrm{Au}-\mathrm{Hg}$ solid solutions and intermetallic alloys in the rodingites of the Zolotaya Gora gold deposit (Urals, Russia). Ore Geol. Rev. 2018, 93, 81-97. [CrossRef]

55. Knight, J.; Leitch, C.H. Phase relations in the system Au-Cu-Ag at low temperatures, based on natural Assemblages. Can. Miner. 2001, 39, 889-905. [CrossRef]

56. Surenkov, S.V.; Moralev, G.V.; Borisov, A.V. Physicochemical Parameters of the Au-PGE-REE Mineralization of the Chudnoe and Nesterovskoe Ore Occurrences (Subpolar Urals); VII Student School Metallogeny of Ancient and Modern Oceans-2001; Institute of Mineralogy, Ural Branch of RAS: Miass, Russia, 2001; pp. 195-198. (In Russian with English abstract)

57. Omelyanenko, B.I. Near-Ore Hydrothermal Alteration of Rocks; Nedra: Moscow, Russia, 1978; p. 215. (In Russian)

58. Prokofiev, V.Y. Geochemical Features of Ore-Forming Fluids of Hydrothermal Gold Deposits of Various Genetic Types (According to the Study of Fluid Inclusions); Zorina, L.D., Ed.; Siberian Publishing Company “Science": Novosibirsk, Russia, $2000 ;$ p. 192.

59. Berni, G.V.; Heinrich, C.A.; Wälle, M.; Wall, V.J. Fluid geochemistry of the Serra Pelada Au-Pd-Pt deposit, Carajás, Brazil: Exceptional metal enrichment caused by deep reaching hydrothermal oxidation. Ore Geol. Rev. 2019, 111, 102991. [CrossRef]

60. Barakat, A.; Marignac, C.; Boiron, M.-C.; Bouabdelli, M. Caractérisation des paragenèses et des paléocirculations fluides dans l'indice d'or de Bleïda (Anti-Atlas, Maroc). Comptes Rendus Geosci. 2002, 334, 35-41. [CrossRef]

61. El Ghorfi, M.; Oberthür, T.; Melcher, F.; Lüders, V.; Boukhari, A.; Maacha, L.; Ziadi, R.; Baoutoul, H. Gold-palladium mineralization at Bleïda Far West, Bou Azzer-El Graara Inlier, Anti-Atlas, Morocco. Miner. Depos. 2006, 41, 549-564. [CrossRef]

62. Berni, G.V.; Heinrich, C.A.; Lobato, L.M.; Wall, V. Ore mineralogy of the Serra Pelada Au-Pd-Pt deposit, Carajás, Brazil and implications for ore-forming processes. Miner. Deposita 2016, 51, 781-795. [CrossRef]

63. Palyanova, G.A. Gold and Silver Minerals in Sulfide Ore. Geol. Ore Depos. 2020, 62, 383-406. [CrossRef]

64. Zaccarini, F.; Pushkarev, E.; Fershtater, G.B.; Garuti, G. Composition and mineralogy of PGE-rich chromitites in the nurali lherzolite gabbro complex, Southern Urals, Russia. Can. Miner. 2004, 42, 545-562. [CrossRef]

65. Anikina, E.V.; Zaccarini, F.; Knauf, V.V.; Rusin, I.A.; Pushkarev, E.V.; Garouti, J. Palladium and gold minerals in the ores of the Baron ore occurrence, Volkovsky gabbro-diorite massif. Bull. Ural Dep. Rus. Mineral. Soc. 2005, 4, 5-25. (In Russian with English abstract)

66. Spiridonov, E.; Yanakieva, D. Modern mineralogy of gold: Overview and new data. ArchéoSciences 2009, 33, 67-73. [CrossRef]

67. Kuznetsov, S.K.; Tarbaev, M.B.; Moralev, G.V.; Soboleva, A.A.; Ivanova, T.I. Gold-platinoid mineralization in the Subpolar Urals. In Mater. Vseros. Conf. "Gold, Platinum and Diamonds of the Komi Republic and Adjacent Regions"; Institute of Geology, Komi Science Center: Syktyvkar, Russia, 1998; pp. 13-14. (In Russian with English abstract) 
68. Buisson, G.; Leblanc, M. Gold bearing listwanites (carbonatized ultramafic rocks) in ophiolite complexes. In Metallogeny of Basic and Ultrabasic Rocks; Gallagher, J.M., Iscer, R.A., Neary, C.R., Prichard, H.M., Eds.; Institute of Mining and Metallurgy: London, UK, 1986; pp. 121-132.

69. Halls, C.; Zhao, R. Listvenite and related rocks: Perspectives on terminology and mineralogy with reference to an occurrence at Cregganbaum, Co., Mayo, Republic of Ireland. Miner. Depos. 1995, 30, 303-313. [CrossRef]

70. Azer, M.K. Evolution and economic significance of listwaenites associated with Neoproterozoic ophiolites in south Eastern Desert, Egypt. Geol. Acta 2013, 11, 113-128.

71. Belogub, E.V.; Melekestseva, I.Y.; Novoselov, K.A.; Zabotina, M.V.; Tret'Yakov, G.A.; Zaykov, V.V.; Yuminov, A.M. Listveniterelated gold deposits of the South Urals (Russia): A review. Ore Geol. Rev. 2017, 85, 247-270. [CrossRef]

72. Sazonov, V.N. Gold-Bearing Metasomatic Associations in Fold Belts; Institute of Geology and Geochemistry: Yekaterinburg, Russia, 1998; p. 181. (In Russian)

73. Zharikov, V.A.; Rusinov, V.L. Metasomatism and Metasomatic Rocks; Scientific World: Moscow, Russia, $1998 ;$ p. 492.

74. Harlov, D.E.; Austrheim, H. Metasomatism and the Chemical Transformation of Rock; Metzler, J.B., Ed.; Springer: Berlin/Heidelberg, Germany, 2013; p. 806. 